\title{
Democratic Change in the Arab World, Past and Present
}

\begin{abstract}
Will the Arab Spring lead to long-lasting democratic change? To explore this question, I examine the determinants of the Arab world's democratic deficit in 2010. I find that the percentage of a country's landmass that was conquered by Arab armies following the death of the prophet Muhammad statistically accounts for this deficit. Using history as a guide, I hypothesize that this pattern reflects the long-run influence of control structures developed under Islamic empires in the premodern era and find that the available evidence is consistent with this interpretation. I also investigate the determinants of the recent uprisings. Taken in unison, the results cast doubt on claims that the Arab-Israeli conflict or Arab culture or Muslim theology is a systematic obstacle to democratic change in the region and point instead to the legacy of the region's historical institutional framework.
\end{abstract}

W ill the Arab Spring lead to long-lasting democratic change? With Islamist parties and candidates performing well in elections across the Arab world, many observers have begun to predict that the recent uprisings will usher in a wave of Islamist-dominated autocracies instead of the democratic institutions many protestors initially demanded. These observers often point to the political trajectories of non-Arab, Muslim-majority states such as Iran and implicitly claim that Islamist-dominated states cannot be democratic. Others note that the emergence of democratic regimes in Indonesia and Turkey demonstrate that Islamists can play a constructive role in democratic institutions. ${ }^{1}$

One challenge for those interested in forecasting the evolution of institutions in the Arab world is that there is little consensus regarding the factors that led to the region's democratic deficit before the recent uprisings. Some

1. For an example of this debate, see the article on Islamists, elections, and the Arab Spring in The Economist, December 10, 2011 (www.economist.com/node/21541404).

Brookings Papers on Economic Activity, Spring 2012

Copyright 2012, The Brookings Institution 
Figure 1. Democracy in the Eastern Hemisphere, 2010, and the Arab Conquest Region

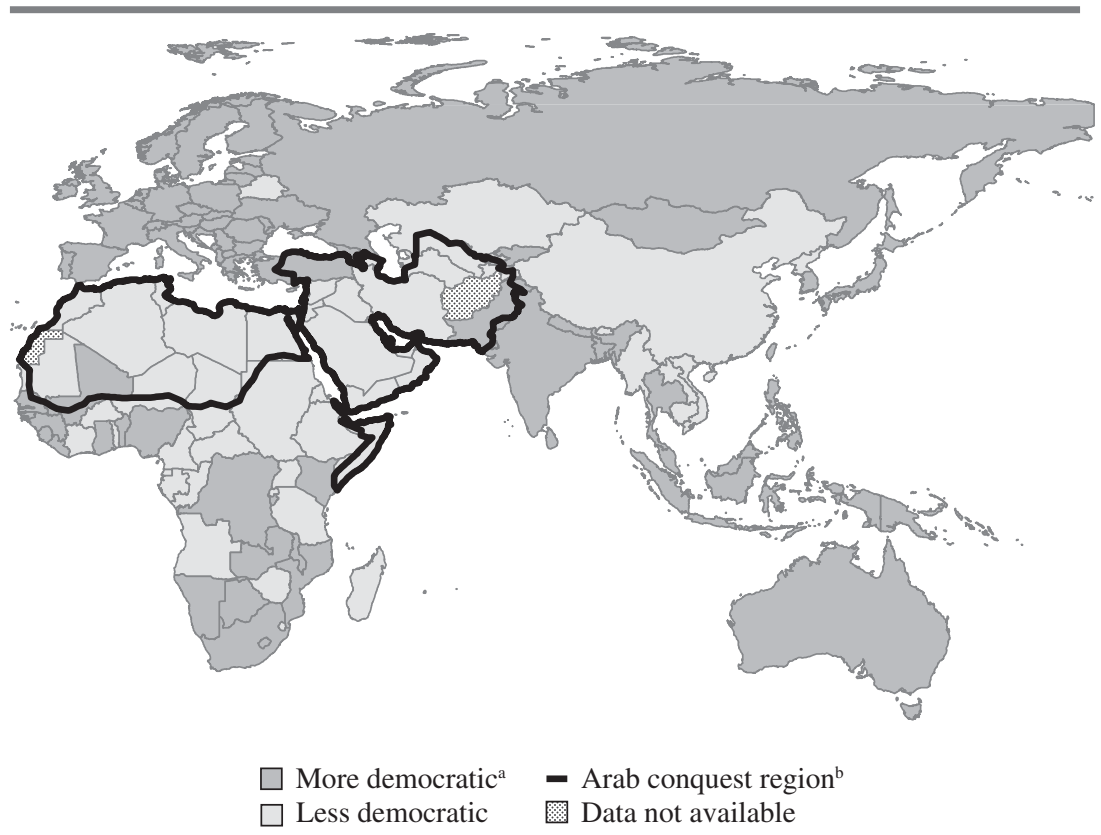

Sources: Polity IV Project; Kennedy (2002, section II).

a. Countries with a polity score greater than 3 .

b. Lands persistently controlled by Islamic empires from 1100 to $1900 \mathrm{CE}$.

studies stress the effects of the ongoing Arab-Israeli conflict (Elbadawi and Makdisi 2007), while others highlight factors as diverse as the subservient status of women (Fish 2002), fossil-fuel wealth (Ross 2001), Muslim culture or religious beliefs (Huntington 1996), or Arab-specific cultural or institutional characteristics (Sharabi 1988, Noland 2008). Many of these studies reach conflicting conclusions. They also fail to explain why the "Arab democratic deficit" seems to extend to neighboring non-Arab, Muslim-majority countries but not to other Muslim-majority regions.

Figure 1 shows the geographic clustering of less democratic regimes in and around the Arab world as of $2010 .^{2}$ The concentration of nondemocra-

2. Students of Islamic history will note that the boundaries in figure 1 do not exactly correspond to the regions conquered by Arab armies. Throughout the paper, for expositional simplicity I use the shorthand "conquered by Arab armies" to denote early and persistent incorporation into the Islamic world: those countries that had at least half of their present-day landmass more or less continuously controlled by Islamic dynasties since at least $1100 \mathrm{CE}$. See section I for a more detailed discussion. 
cies within the outlined areas, those conquered by Arab armies in the centuries following the death of the prophet Muhammad in $632 \mathrm{CE}$, is striking and suggests a possible explanation for why countries such as Chad, Iran, and Uzbekistan share the Arab League's democratic deficit today whereas other Muslim-majority countries such as Albania, Bangladesh, and Indonesia do not. I hypothesize that the countries in the first group were more exposed to the institutional framework that developed following Arab conquests than those in the second, and that these historical arrangements, in turn, have had enduring effects that help explain the clustering evident in figure 1 .

To investigate the empirical relevance of this hypothesis, I calculate the percentage of a country's landmass that was conquered by Arab armies in the centuries following the death of Muhammad. I then show that from a statistical standpoint this variable accounts for the Arab League's democratic deficit today. This empirical pattern is interesting, in part, because it provides an opportunity to distinguish among a number of competing theories regarding the determinants of the Arab world's democratic deficit on the eve of the recent uprisings. For example, the fact that this deficit is shared by 10 non-Arab countries that were conquered by Arab armies casts doubt on the importance of Arab culture in perpetuating the democratic deficit. Hypotheses stressing the role of Muslim theology also do not receive empirical support: once one accounts for the 28 countries conquered by Arab armies, the evolution of democracy in the remaining 15 Muslim-majority countries since 1960 largely mirrors that of the rest of the developing world.

Alternative views attribute the region's democratic deficit to the effects of oil wealth, the Arab-Israeli conflict, or the region's desert terrain with its low suitability for rain-fed agriculture (Haber and Menaldo 2011). But once one accounts for oil-endowed countries, countries involved in the Arab-Israeli conflict, or suitability for agriculture, the results are almost identical to those obtained when these controls are omitted. Consequently, my reading of the evidence provides little support for these hypotheses.

A final group of hypotheses, which I believe provides the best explanation for the empirical patterns I document, is the "institutional persistence" hypothesis (Acemoglu, Johnson, and Robinson 2001, 2002, Nunn 2008, 2009, Dell 2010). Many scholars maintain that the roots of the Arab world's democratic deficit are to be found in the region's history of "unrelieved autocracy" (Lewis 1993b), which dates back to the early 9th century (Khashan 1998). This view builds on a distinguished line of scholarship going back at least to Montesquieu (1989 [1748]) suggesting that 
historical developments in the Islamic Middle East have made the region particularly prone to autocratic rule. ${ }^{3}$

If the Arab League's democratic deficit today can be traced to the longterm effects of the region's historical control structures, what specific developments following the Arab conquests had such enduring effects? It is well known that a highly distinctive institutional framework emerged in the regions conquered by Arab armies (Hodgson 1974, p. 64), an important part of which was that rulers enforced their authority through armies staffed primarily by slaves (Blaydes and Chaney 2011). This practice was a "major innovation" and led to "vast changes in the organization of society" (Lapidus 2002, pp. 104, 108). Scholars believe that the widespread use of slave armies allowed rulers to undermine the power bases of local elites, leading to their destruction. As political power became increasingly concentrated in the hands of military leaders backed by slave armies, religious leaders emerged as the only check on the sovereign's power (Chaney 2011, 2012). The use of slave armies appears to have impeded the emergence of other groups, such as a landed nobility or coalitions of merchants, that could have helped constrain the sovereign.

This political equilibrium persisted in many areas into the 19th century and is thought to have left a legacy of both weak institutions and weak civil societies (see, for example, Kuran 2011, p. 301, Chaney 2012). Although it is difficult to measure the extent to which institutions and civil societies are abnormally weak in areas conquered by Arab armies, I find that the available data are consistent with this hypothesis.

Have the numerous structural changes in the region over the past decades (Rauch and Kostyshak 2009) helped lessen the weight of history, making Arab states fertile ground for sustained democratic change? Since data limitations preclude a systematic investigation of the channels through which the region's autocratic institutions have persisted, my strategy will be simply to investigate the characteristics of countries that experienced uprisings in 2011. The most robust finding that emerges is that countries that experienced uprisings witnessed significantly lower levels of selfreported well-being in the year before the uprisings. This result suggests that the Arab Spring shares characteristics with other popular movements elsewhere in the world that have led to long-lasting democratic transitions (Acemoglu and Robinson 2006).

3. Some of these scholars have stressed that the introduction of Islamic beliefs was a key historical event that aided both the development and subsequent persistence of autocratic institutions. 
On the one hand, the results provide reasons to be cautiously optimistic that the Arab Spring will lead to sustained democratic change. For example, they cast doubt on claims that Muslim theology, or the Arab-Israeli conflict, or Arab culture is a systematic obstacle to democracy. On the other hand, they provide sobering evidence that the region's democratic deficit has deep historical roots. Although such impediments to democratic change may have been weakened by the structural changes of the past decades, it is also possible that they remain in place today. In this sense, the interpretation that I believe best explains the empirical patterns I observe echoes recent studies suggesting that the region's democratic deficit is more a product of its unique political equilibrium than of its cultural, ethnic, or religious characteristics (see, for example, Stepan and Robertson 2003, Jamal and Tessler 2008).

Inasmuch as the region's institutional history is useful for forecasting the future, it suggests that democracy is less likely to emerge where political power remains largely divided between religious leaders and the military to the exclusion of other groups (as in Egypt or Yemen, for example). Where instead the first two groups share political power with additional groups (as in Tunisia, for example), Islamist groups may play an important role in sustaining democratic institutions by constraining (and being constrained by) these rival political groups. However, since recent history suggests that Islamists are just as likely as other groups to establish autocratic rule in the absence of checks on their power, popular support for Islamists may undermine democratic efforts if such groups are not checked by other contenders for power.

Finally, it is important to stress that although this paper provides new empirical evidence for the reasons behind the Arab world's democratic deficit, our understanding of the determinants of democracy in the region remains incomplete. This fact provides both an impetus for future research and reasons to be cautious about the evidence we have regarding democratic change in the Arab world, at least as a guide for future policy decisions.

\section{Arab Conquest and Democracy: The Empirical Evidence}

Historical evidence (presented in greater detail in section III) suggests that the Arab League's democratic deficit may not be limited to the modern-day member states of the Arab League. This evidence suggests that modern-day membership in the Arab League is proxying for a history of Arab conquest, or for treatment with the institutional framework developed in the early 
Islamic world. At first glance, this explanation seems largely consistent with the data. For example, 18 of the 21 countries that were members of the Arab League in 2010 (table 1) were conquered by Arab armies in the centuries after the death of the prophet Muhammad (only Comoros, Djibouti, and Sudan were not). Similarly, the non-Arab League countries that were conquered by Arab armies include many, such as Chad, Iran, and Uzbekistan, that share the Arab League countries' relative lack of democracy. Despite this fact, to the best of my knowledge this hypothesis has yet to be empirically examined. ${ }^{4}$ In this section I show that the empirical evidence is consistent with the hypothesis that the "Arab democratic deficit" is a product of the long-run legacy of the control structures developed in the early Islamic world. ${ }^{5}$

\section{I.A. Arab Conquest and Democracy in 2010}

To measure the extent to which countries were persistently exposed to the institutional framework developed in the early Islamic world, I define the variable ArabConquest as the proportion of a country's landmass that was ruled by Muslim dynasties in the year $1100 \mathrm{CE}$ interacted with an indicator variable that equals 1 if at least half of the country's landmass was under Muslim rule in 1900 CE. (I set ArabConquest equal to zero for Israel.) This metric excludes areas, such as Spain, that lost the relevant institutional framework centuries ago. Since the majority of the lands under the control of Muslim dynasties in $1100 \mathrm{CE}$ had been conquered by Arab armies, for expositional simplicity I use "Arab conquest" to refer to early incorporation into the Islamic world.

Table 2 investigates the extent to which ArabConquest can statistically account for the democratic deficit in the Muslim world in general and the Arab League in particular. I estimate a regression of the form

$$
\begin{aligned}
\text { Democracy }_{i c}= & \beta_{1} \text { Muslim }_{i c}+\beta_{2} \text { ArabLeague }_{i c} \\
& +\beta_{3} \text { ArabConquest }_{i c}+\gamma^{\prime} X+\varepsilon_{i c},
\end{aligned}
$$

4. Rowley and Smith (2009) note that the Muslim world's democratic deficit seems to be larger in the "Islamic heartland," which roughly corresponds to the areas conquered by Arab armies, but they leave out several countries that were incorporated early into the Islamic world. This may help explain why they conclude that the deficit seems "to have something to do with Islam itself."

5. For expositional ease I leave the description of the majority of the data used in the paper to the appendix. 


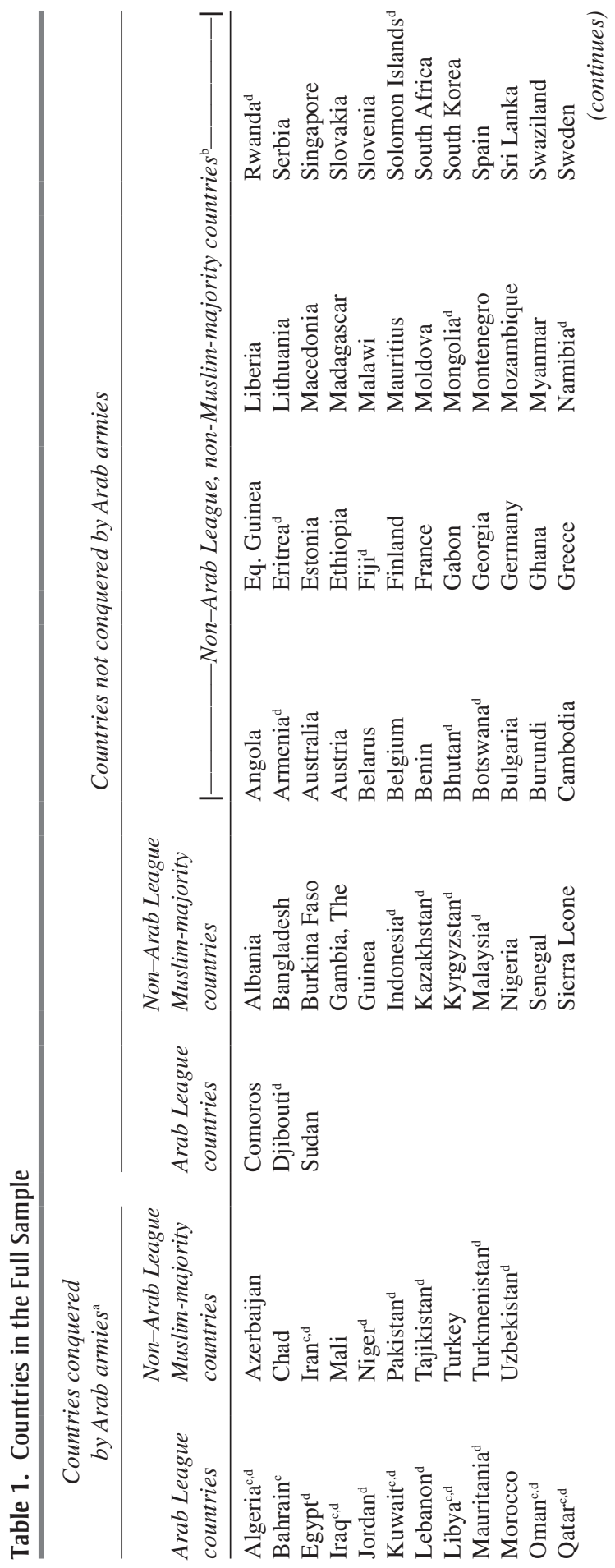




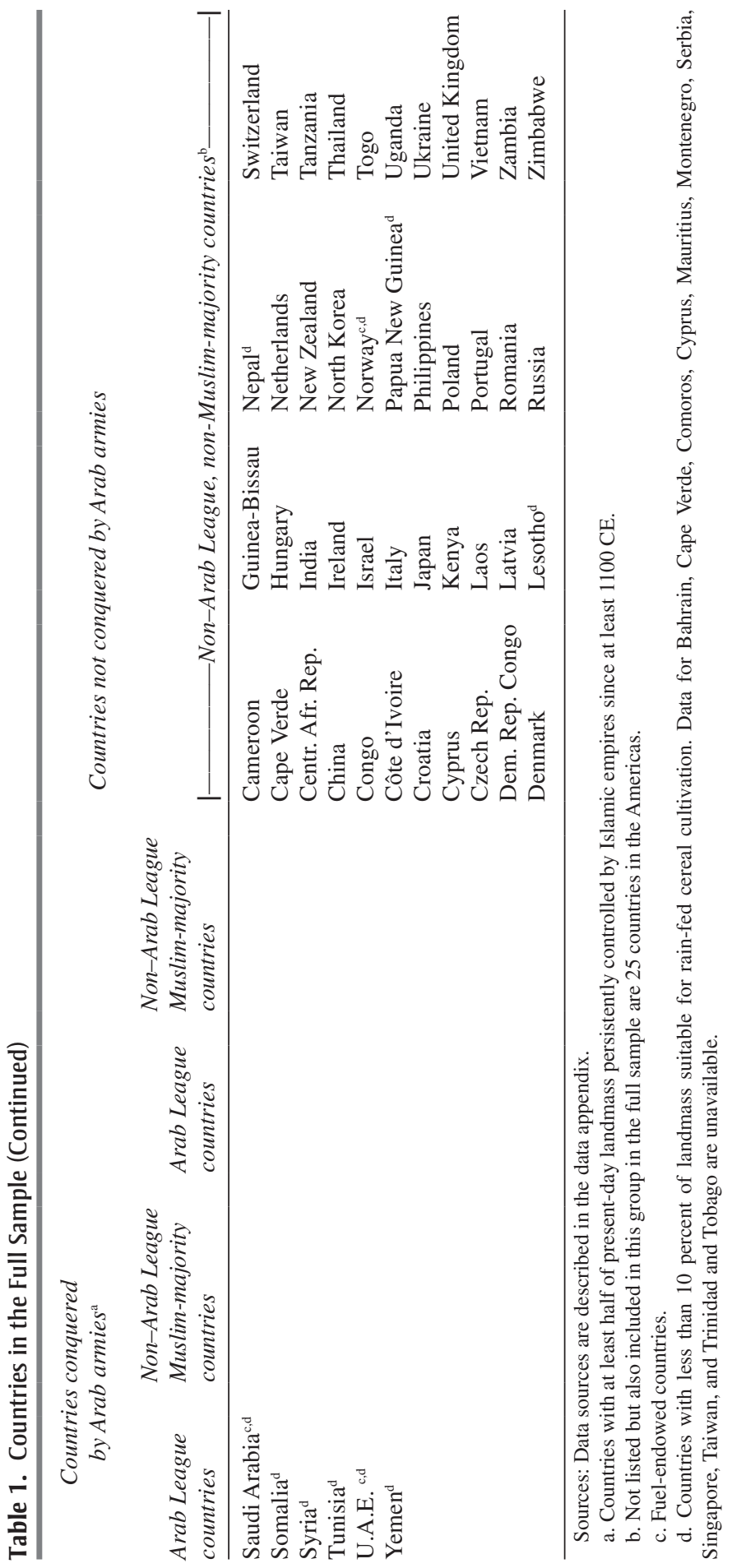




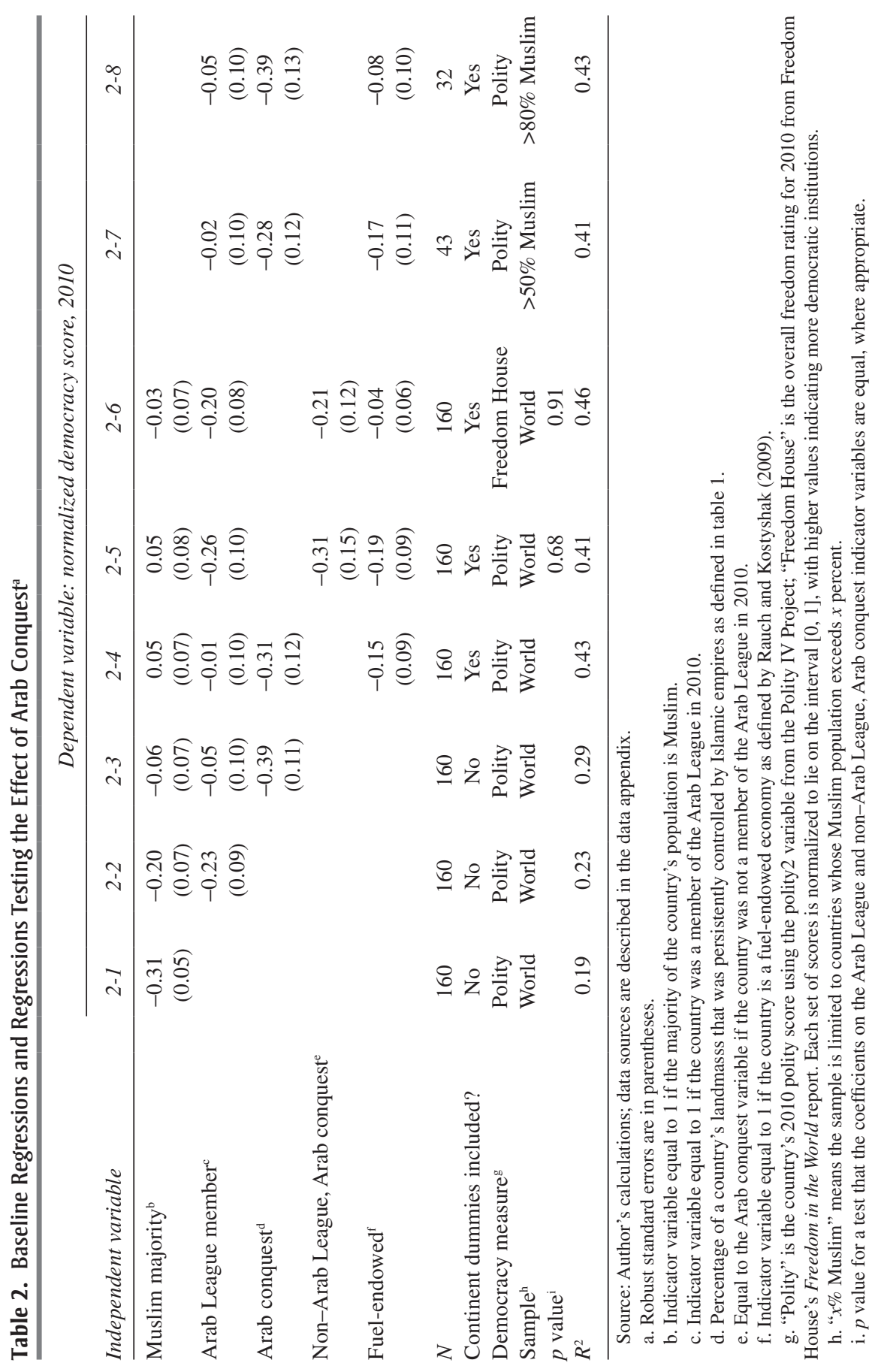


where Democracy ${ }_{i c}$ is the normalized polity score of country $i$ on continent $c$ in 2010 (where the normalized polity score lies on the interval $[0,1]$, with higher values denoting more democratic institutions), Muslim $_{i c}$ is an indicator variable equal to 1 if over half of the country's population is Muslim, ArabLeague $_{i c}$ is an indicator equal to 1 if the country was a member of the Arab League in 2010, ArabConquest ${ }_{i c}$ is as defined above, and $X$ is a vector of covariates including continent dummies and an indicator equal to 1 if James Rauch and Scott Kostyshak (2009) define the country as fuel-endowed.

The regression reported in column 2-1 of table 2 estimates $\beta_{1}$ with all other covariates aside from an intercept omitted. The point estimate shows that Muslim-majority countries are 0.31 normalized polity point (roughly 1 standard deviation) less democratic than the average for the rest of the world. Column 2-2 adds the indicator variable for Arab League membership. The coefficient on Muslim $_{i c}$ decreases in absolute value but remains negative and statistically significant. The coefficient on ArabLeague ${ }_{i c}$ is also negative and statistically significant. These results are consistent with previous studies that have found both Arab and Muslim democratic deficits.

Column 2-3 adds the variable ArabConquest ${ }_{i c}$. The point estimates on the variables Muslim $_{i c}$ and ArabLeague $i c$ now drop sharply in absolute value and become statistically insignificant. Column 2-4 adds continent dummies and the dummy variable for fuel endowment. The results do not change qualitatively and show that from a statistical standpoint, ArabConquest $_{i c}$ explains both the Arab and the Muslim democratic deficits found in previous studies.

Column 2-5 replaces ArabConquest ${ }_{i c}$ with a new variable equal to ArabConquest ${ }_{i c}$ if the country was not a member of the Arab League. The coefficient on this variable is statistically indistinguishable from that on ArabLeague $_{i c}$. Column 2-6 reports results of an identical regression replacing Democracy ${ }_{i c}$ with the overall freedom rating from Freedom House's Freedom in the World report, another widely used measure of the strength of democratic institutions. As with Democracy ${ }_{i c}$, this score is normalized to lie on the interval $[0,1]$, with higher values denoting more-democratic institutions. The results remain robust to this exercise.

Column 2-7 limits the sample to countries that have Muslim population shares greater than 0.5 . These results show that within the Muslim-majority world, the Arab League's democratic deficit is shared by countries that were conquered by Arab armies. Column 2-8 shows that the result continues to hold when one increases the cutoff to include only those countries whose Muslim share exceeds 0.8 . 
Figure 2. Democracy in Arab Conquest and Non-Arab Conquest Countries, 1960-2010

Normalized polity score

$(1.0=$ most democratic $)$

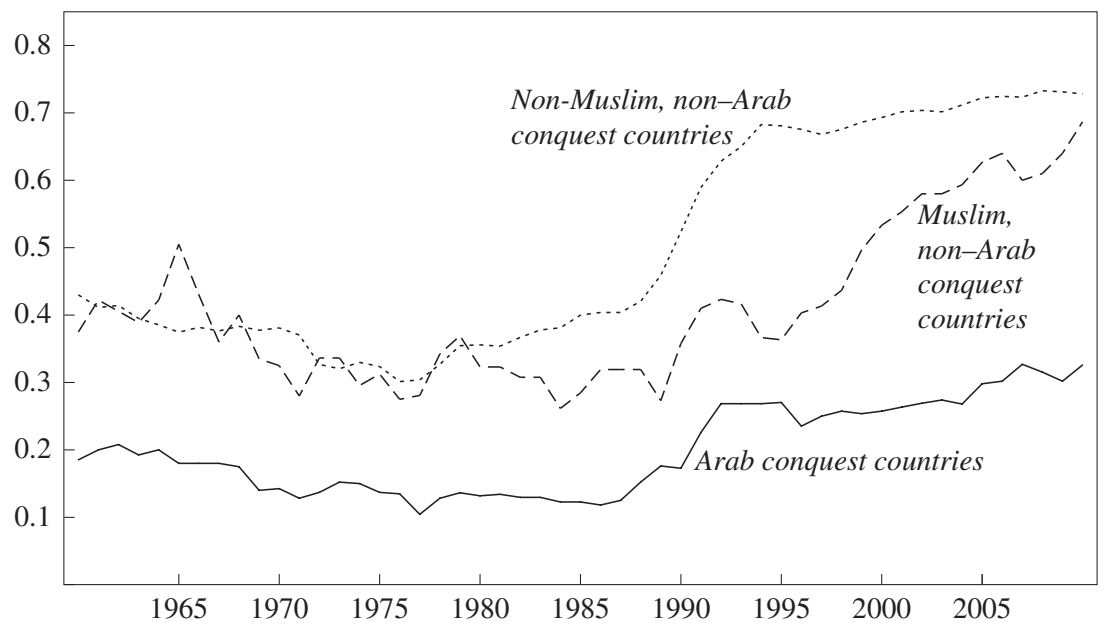

Source: Polity IV Project data; author's calculations.

\section{I.B. The Emergence of the Democratic Deficit}

The evidence presented so far documents that countries conquered by Arab armies were more likely than others to have a democratic deficit in 2010. When did this deficit emerge? To examine this question, figure 2 plots the average polity score since 1960 of developing countries in each of three groups: ${ }^{6}$ countries that were conquered by Arab armies, Muslimmajority countries that were not conquered by Arab armies, and nonMuslim-majority countries that were not conquered by Arab armies.

In 1960, when the majority of the developing world had been decolonized, both Muslim-majority non-Arab conquest countries and non-Muslim developing countries had average normalized polity scores of roughly 0.4 . The scores in countries that were conquered by Arab armies were markedly lower, at around 0.2 . Until around 1990 this gap of around 0.2 point remained roughly constant. After 1990 the non-Muslim developing world experienced a wave of democratization that was followed by

6. I define developing countries as those that were not members of the Organisation for Economic Co-operation and Development before 1980. The qualitative implications of the analysis are robust to alternative definitions. Before 1960, small sample sizes limit the analysis. 
the non-Arab conquest Muslim countries with a lag of roughly 10 years. Although countries conquered by Arab armies have seen a slow trend toward increasing political openness since 1990, levels of democracy in this region in 2010 remained well below those in the rest of the developing world.

In sum, the democratic deficit of countries that were conquered by Arab armies dates back at least to 1960. Although systematic statistical analyses are not possible before this date, the average normalized polity score remains approximately constant before 1960 in the two Arab conquest countries, Iran and Turkey, where these scores go back to 1800 . This result is consistent with the claim that the region's democratic deficit has deep historical roots.

\section{Hypotheses and Explanations for the Arab World's Democratic Deficit}

This section examines the extent to which prominent hypotheses for the Arab world's democratic deficit on the eve of the Arab Spring are consistent with the empirical evidence presented above.

\section{II.A. The Culture Hypothesis}

The culture hypothesis claims that the Arab League's democratic deficit is a product of the region's culture. One version of this hypothesis is that Arab culture is inimical to the emergence of democratic institutions (Sharabi 1988, Noland 2008). The empirical evidence presented so far is not consistent with this hypothesis. Of the 28 countries in the sample that were conquered by Arab armies, 18 are members of the Arab League today whereas 10 are not. There is no evidence that the 18 members have systematically lower polity scores than the 10 nonmembers. Since membership in the Arab League is generally used as a proxy for Arab culture, this result casts doubt on the importance of Arab culture in perpetuating the observed democratic deficit.

Another version of the culture hypothesis suggests that Muslim religious beliefs are responsible for the region's democratic deficit (Huntington 1996, Lakoff 2004). However, table 2 showed that once one controls for Arab conquest, the coefficient on the variable for a Muslim-majority population is small and not statistically significant. This result is not consistent with claims that Muslim theology or gender norms in the Islamic world are responsible for the region's democratic deficit (Fish 2002).

Are these results driven by the fact that areas that were incorporated early into the Islamic world are more religious? Table 3 explores this possibility. Column 3-1 presents for comparison the estimates of equation 1, this 
Table 3. Regressions Testing the Effects of Religiosity and Islamic Norms ${ }^{a}$

\begin{tabular}{|c|c|c|c|c|c|c|}
\hline \multirow[b]{2}{*}{ Independent variable } & \multicolumn{6}{|c|}{ Dependent variable: normalized polity score, $2010^{\mathrm{b}}$} \\
\hline & $3-1$ & $3-2$ & $3-3$ & $3-4$ & $3-5$ & $3-6$ \\
\hline Arab conquest & $\begin{array}{c}-0.32 \\
(0.09)\end{array}$ & $\begin{array}{c}-0.33 \\
(0.10)\end{array}$ & $\begin{array}{c}-0.35 \\
(0.10)\end{array}$ & $\begin{array}{c}-0.32 \\
(0.09)\end{array}$ & $\begin{array}{c}-0.26 \\
(0.10)\end{array}$ & $\begin{array}{c}-0.36 \\
(0.09)\end{array}$ \\
\hline Muslim majority & $\begin{array}{c}0.05 \\
(0.07)\end{array}$ & $\begin{array}{c}0.03 \\
(0.07)\end{array}$ & $\begin{array}{c}0.03 \\
(0.08)\end{array}$ & $\begin{array}{c}0.06 \\
(0.07)\end{array}$ & & \\
\hline Religiosity $^{\mathrm{c}}$ & & $\begin{array}{c}0.13 \\
(0.20)\end{array}$ & & & $\begin{array}{c}0.65 \\
(0.37)\end{array}$ & \\
\hline Women in parliament $\mathrm{d}^{\mathrm{d}}$ & & & $\begin{array}{c}-0.27 \\
(0.22)\end{array}$ & & & \\
\hline Fertility rate ${ }^{e}$ & & & & $\begin{array}{c}-0.01 \\
(0.02)\end{array}$ & & \\
\hline Alcohol consumption ${ }^{\mathrm{f}}$ & & & & & & $\begin{array}{c}-0.03 \\
(0.01)\end{array}$ \\
\hline$N$ & 160 & 134 & 147 & 156 & 36 & 43 \\
\hline Sample & World & World & World & World & $\begin{array}{c}>50 \% \\
\text { Muslim }\end{array}$ & $\begin{array}{l}>50 \% \\
\text { Muslim }\end{array}$ \\
\hline$R^{2}$ & 0.43 & 0.44 & 0.42 & 0.43 & 0.42 & 0.48 \\
\hline
\end{tabular}

Source: Author's calculations; data sources are described in the data appendix.

a. The Arab conquest and Muslim majority variables and the samples are as defined in table 2. All regressions include continent dummies and the fuel-endowed indicator variable from table 2. Robust standard errors are in parentheses.

b. Country's 2010 polity score on the polity 2 variable from the Polity IV Project, normalized as described in table 2 .

c. Country average of the religiosity index from the Gallup World Poll between 2005 and 2011, with higher values indicating more religiosity.

d. Percentage of a country's national parliamentary seats in a single or lower chamber held by women in 2010 .

e. Country's fertility rate in 2010 .

f. Country's total average alcohol consumption per capita in liters of pure alcohol.

time omitting the Arab League dummy for expositional simplicity. Column 3-2 adds a measure of self-reported religiosity. The coefficient on Arab conquest remains robust. Indeed, the data provide little evidence that individuals in Arab conquest countries are more religious than those elsewhere. Column 3-3 includes the percentage of parliamentary seats held by women, and column 3-4 includes the fertility rate in 2010. The results again remain robust to the inclusion of these proxies for the position of women in society.

Columns 3-5 and 3-6 limit the sample to the Muslim-majority world. Column 3-5 includes self-reported religiosity, and column 3-6 includes alcohol consumption per capita. Since Islam prohibits alcohol consumption, this metric serves as another proxy for religiosity. The results remain robust to the inclusion of these controls. Since these metrics provide little 
evidence that the inhabitants of Arab conquest areas are more religious than nonconquest Muslim populations, the results are not consistent with the hypothesis that Islamic culture or theology is the primary obstacle to democracy in the region. ${ }^{?}$

\section{II.B. The Arab-Israeli Conflict and Resource Curse Hypotheses}

Another group of studies stresses the Arab-Israeli conflict (Stepan and Robertson 2003, Elbadawi and Makdisi 2007, Diamond 2010) as a determinant of the region's democratic deficit. Such studies explicitly claim that any negative effects on democratic outcomes should be limited to the Arab world. However, as shown above, the democratic deficit extends to a sizable number of countries outside of the Arab League. These results cast doubt on the importance of the Arab-Israeli conflict as a systematic obstacle to democratic change across the region.

Another influential literature argues that large amounts of oil wealth are inimical to the development of democratic institutions (Ross 2001). Are the results above driven by oil-rich countries? Recall that the regressions in table 2 that included a dummy variable denoting fuel-endowed countries as defined in Rauch and Kostyshak (2009) found that this variable does not qualitatively affect the results. In other words, the data do not support the hypothesis that oil wealth drives the Arab League's democratic deficit. ${ }^{8}$

\section{II.C. Desert Terrain and Settled Agriculture}

In a recent working paper, Stephen Haber and Victor Menaldo (2011) document an interesting statistical relationship between rainfall and democracy. They hypothesize that certain types of rain-fed agriculture led to historical developments that proved favorable to the emergence of stable democratic institutions. This hypothesis raises the possibility that the results reported above reflect the fact that many areas conquered by Arab armies were not suitable for the development of rain-fed agriculture.

Table 4 investigates this possibility. Column 4-1 repeats the results of regression 3-1 for comparison (again omitting the Arab League dummy). Columns 4-2 and 4-3 add the logarithm of a country's average rainfall in both linear and cubic specifications as suggested by Haber and Menaldo

7. These findings thus echo the conclusions of recent analyses such as Stepan and Robertson (2003) or Jamal and Tessler (2008).

8. I do present evidence later in the paper, however, consistent with the claim that popular pressures for democratization are more muted in oil-rich counties. Consequently, the results in the paper are not inconsistent with the hypothesis that oil wealth discourages the emergence of democratic institutions. Rather, they suggest that oil wealth cannot account for the entire region's democratic deficit. 
Table 4. Regressions Testing the Effects of Desert Terrain and Agricultural Suitability

\begin{tabular}{|c|c|c|c|c|c|}
\hline \multirow[b]{2}{*}{ Independent variable } & \multicolumn{5}{|c|}{ Dependent variable: normalized polity score, 2010} \\
\hline & $4-1$ & $4-2$ & $4-3$ & $4-4$ & $4-5$ \\
\hline Arab conquest & $\begin{array}{c}-0.32 \\
(0.09)\end{array}$ & $\begin{array}{c}-0.30 \\
(0.14)\end{array}$ & $\begin{array}{c}-0.28 \\
(0.14)\end{array}$ & $\begin{array}{c}-0.28 \\
(0.12)\end{array}$ & $\begin{array}{c}-0.30 \\
(0.10)\end{array}$ \\
\hline Muslim majority & $\begin{array}{c}0.05 \\
(0.07)\end{array}$ & $\begin{array}{c}0.05 \\
(0.07)\end{array}$ & $\begin{array}{c}0.04 \\
(0.07)\end{array}$ & $\begin{array}{c}0.05 \\
(0.07)\end{array}$ & $\begin{array}{c}0.05 \\
(0.07)\end{array}$ \\
\hline $\ln (\text { rainfall })^{\mathrm{b}}$ & & $\begin{array}{c}0.01 \\
(0.04)\end{array}$ & $\begin{array}{c}1.99 \\
(1.97)\end{array}$ & & \\
\hline $\ln ^{2}($ rainfall $)$ & & & $\begin{array}{c}-0.30 \\
(0.34)\end{array}$ & & \\
\hline $\ln ^{3}($ rainfall $)$ & & & $\begin{array}{c}0.02 \\
(0.02)\end{array}$ & & \\
\hline Percent desert $^{\mathrm{c}}$ & & & & $\begin{array}{c}0.01 \\
(0.11)\end{array}$ & \\
\hline Cereal suitability ${ }^{\mathrm{d}}$ & & & & & $\begin{array}{c}-0.10 \\
(0.12)\end{array}$ \\
\hline $\begin{array}{l}N \\
p \text { value }\end{array}$ & 160 & 158 & $\begin{array}{l}158 \\
0.39\end{array}$ & 150 & 150 \\
\hline$R^{2}$ & 0.43 & 0.43 & 0.44 & 0.44 & 0.44 \\
\hline
\end{tabular}

Source: Author's calculations; data sources are described in the data appendix.

a. The Arab conquest and Muslim-majority variables are defined as in table 2 . The sample is the world sample. All regressions include continent dummies and the fuel-endowed indicator variable from table 2. Robust standard errors are in parentheses.

b. Logarithm of a country's 2008 average precipitation.

c. Percentage of a country's landmass that is covered by desert terrain.

d. Percentage of a country's landmass that is suitable for rain-fed cereal cultivation.

e. $p$ value for a test that the coefficients on $\ln ($ rainfall $), \ln ^{2}$ (rainfall), and $\ln ^{3}$ (rainfall) are jointly equal to zero, where appropriate.

(2010). Column 4-4 substitutes for these the percentage of a country's landmass covered by desert terrain. The point estimates on the variable ArabConquest $_{i c}$ do not change substantially when these measures are added to the regression, and they remain statistically significant. The coefficients on rainfall and desert terrain, in turn, are small in absolute value and statistically insignificant. Thus, these regressions provide little support for the hypothesis that desert terrain has effects on democratic outcomes today that are independent of Arab conquest.

Figure 3 demonstrates the lack of a relationship between rainfall and democracy outside of the countries conquered by Arab armies. The steeper of the two fitted regression lines shows that this relationship is positive for the entire sample in 2010. However, this relationship is entirely driven by countries conquered by Arab armies. Once these countries are removed, the relationship is no longer statistically significant. 
Figure 3. Rainfall, Democracy, and Arab Conquest

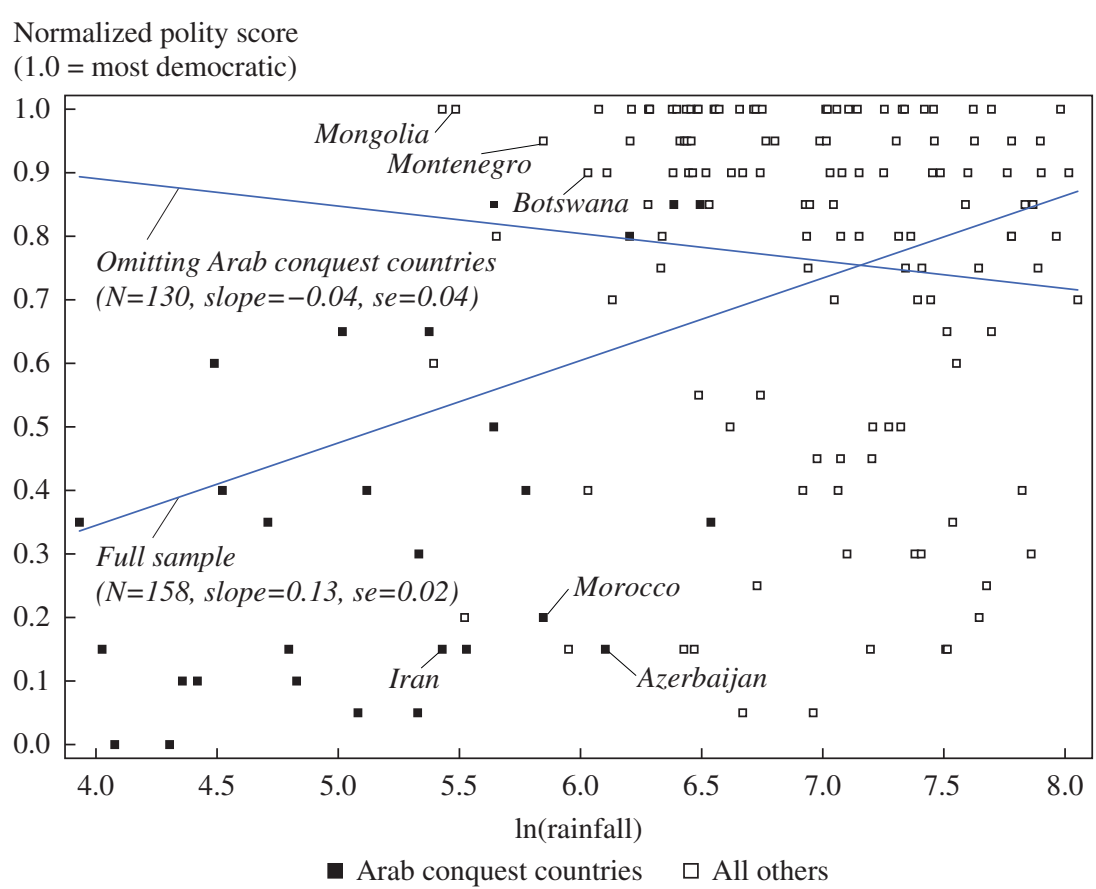

Sources: Polity IV Project data; World Bank data.

Figure 3 also shows that although some Arab conquest and non-Arab conquest countries do have similar levels of rainfall, only a few nonconquest countries, such as Botswana, Mongolia, and Montenegro, have low enough rainfall to be comparable to countries such as Azerbaijan, Iran, or Morocco. Rainfall, however, is just one determinant of how suitable a country's terrain is for settled agriculture. Since Haber and Menaldo (2011, p. 3) stress that suitability for rain-fed grains is a good proxy for the geography they believe to be favorable to the emergence of democratic institutions, I follow Nathan Nunn and Nancy Qian (2011) and use countrylevel data on suitability for growing cereals, from the Food and Agriculture Organization's Global Agro-Ecological Zones 2002 database. ${ }^{9}$ Using these

9. Again following Nunn and Qian, I define land to be suitable for grain cultivation if it is defined in the database as being either "very suitable," "suitable," or "moderately suitable," assuming cultivation occurs under rain-fed conditions and under medium input intensity. See Nunn and Qian (2011) for an overview of these data. 
Figure 4. Grain Suitability, Democracy, and Arab Conquest

Normalized polity score

$(1.0=$ most democratic $)$

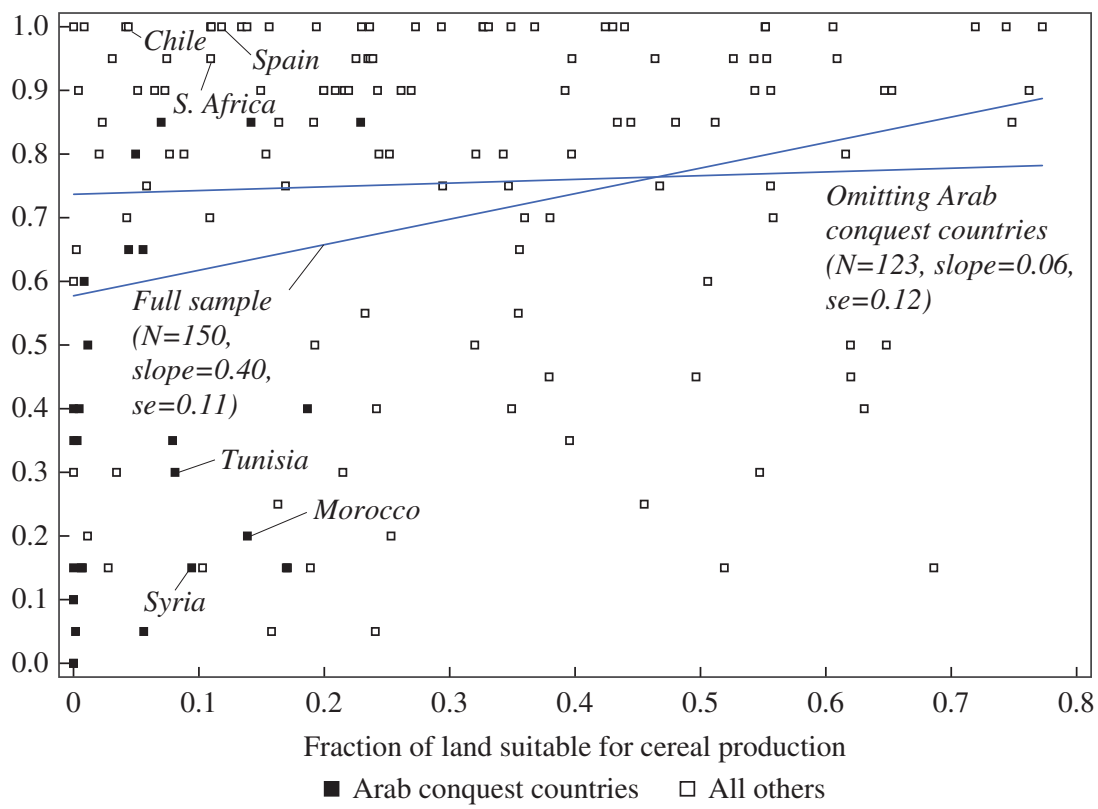

Sources: Polity IV Project data; Food and Agriculture Organization data.

data, I calculate the percentage of a country's landmass that is suitable for grain production. This metric accounts for the fact that in addition to precipitation, variables such as soil quality, mean temperature, wind speed, cloud cover, and ground frost contribute to the suitability of a given region for growing cereals under rain-fed conditions.

Figure 4 shows the relationship between democracy and the percentage of a country's terrain that is suitable for grain cultivation. Again, the relationship is striking for the full sample but disappears when the Arab conquest countries are removed from the sample. Furthermore, when one uses the cereal suitability metric, the number of Arab conquest and non-Arab conquest countries that are similar increases, providing additional evidence that a country's propensity for settled agriculture is not driving the results. For example, more democratic countries as Chile, South Africa, and Spain have low cereal suitabilities that are roughly similar to those in Morocco, Syria, and Tunisia. 
Table 5. Instrumental Variables Regressions Testing the Effect of Arab Conquest ${ }^{\mathrm{a}}$

\begin{tabular}{|c|c|c|c|c|c|c|}
\hline Independent variable & $5-1$ & $5-2$ & $5-3$ & $5-4$ & $5-5$ & $5-6$ \\
\hline \multicolumn{7}{|l|}{ Two-stage least squares ${ }^{\mathrm{b}}$} \\
\hline Arab conquest & $\begin{array}{c}-0.56 \\
(0.30)\end{array}$ & $\begin{array}{c}-0.35 \\
(0.14)\end{array}$ & $\begin{array}{c}-0.37 \\
(0.14)\end{array}$ & $\begin{array}{c}-0.51 \\
(0.17)\end{array}$ & $\begin{array}{c}-0.59 \\
(0.10)\end{array}$ & $\begin{array}{c}-0.58 \\
(0.10)\end{array}$ \\
\hline Muslim majority & $\begin{array}{c}0.17 \\
(0.15)\end{array}$ & $\begin{array}{c}0.07 \\
(0.09)\end{array}$ & $\begin{array}{c}0.08 \\
(0.09)\end{array}$ & & & \\
\hline$R^{2}$ & 0.40 & 0.43 & 0.43 & 0.33 & 0.27 & 0.28 \\
\hline \multicolumn{7}{|c|}{ First stage for Arab conquest ${ }^{c}$} \\
\hline Distance from $\mathrm{Mecca}^{\mathrm{d}}$ & $\begin{array}{c}-0.46 \\
(0.12)\end{array}$ & & $\begin{array}{c}-0.19 \\
(0.11)\end{array}$ & $\begin{array}{c}-1.12 \\
(0.29)\end{array}$ & & $\begin{array}{c}-0.19 \\
(0.40)\end{array}$ \\
\hline $\ln$ (rainfall) & & $\begin{array}{c}-0.17 \\
(0.02)\end{array}$ & $\begin{array}{c}-0.16 \\
(0.02)\end{array}$ & & $\begin{array}{c}-0.29 \\
(0.03)\end{array}$ & $\begin{array}{c}-0.27 \\
(0.06)\end{array}$ \\
\hline$R^{2}$ & 0.70 & 0.77 & 0.78 & 0.49 & 0.65 & 0.65 \\
\hline \multicolumn{7}{|l|}{ Ordinary least squares ${ }^{\mathrm{b}}$} \\
\hline Arab conquest & $\begin{array}{c}-0.32 \\
(0.09)\end{array}$ & $\begin{array}{c}-0.32 \\
(0.09)\end{array}$ & $\begin{array}{c}-0.32 \\
(0.09)\end{array}$ & $\begin{array}{c}-0.29 \\
(0.10)\end{array}$ & $\begin{array}{c}-0.29 \\
(0.10)\end{array}$ & $\begin{array}{c}-0.29 \\
(0.10)\end{array}$ \\
\hline Muslim majority & $\begin{array}{c}0.05 \\
(0.07)\end{array}$ & $\begin{array}{c}0.05 \\
(0.07)\end{array}$ & $\begin{array}{c}0.05 \\
(0.07)\end{array}$ & & & \\
\hline$R^{2}$ & 0.43 & 0.43 & 0.43 & 0.40 & 0.40 & 0.40 \\
\hline $\begin{array}{l}\text { Overidentification tests } \\
p \text { value }^{\mathrm{e}}\end{array}$ & & & 0.63 & & & 0.67 \\
\hline $\begin{array}{l}N \\
\text { Sample }\end{array}$ & $\begin{array}{c}160 \\
\text { World }\end{array}$ & $\begin{array}{c}158 \\
\text { World }\end{array}$ & $\begin{array}{c}158 \\
\text { World }\end{array}$ & $\begin{array}{c}43 \\
>50 \% \\
\text { Muslim }\end{array}$ & $\begin{array}{c}43 \\
>50 \% \\
\text { Muslim }\end{array}$ & $\begin{array}{c}43 \\
>50 \% \\
\text { Muslim }\end{array}$ \\
\hline
\end{tabular}

Source: Author's calculations; data sources are described in the data appendix.

a. The Arab conquest and Muslim-majority variables are as defined as in table 2. The samples are as defined in table 2. The rainfall variable is as described in table 4. All regressions include continent dummies and the fuel-endowed indicator variable from table 2. Robust standard errors are in parentheses.

b. The dependent variable is the 2010 polity score as defined in table 2 .

c. The dependent variable is the Arab conquest variable as defined in table 2.

d. Distance of the country's centroid from Mecca, in tens of thousands of kilometers.

e. $p$ value from the appropriate overidentification test where relevant.

Column 4-5 of table 4 demonstrates this point more formally by adding the cereal suitability metric to the first regression. The results remain robust to this exercise. In sum, the available evidence provides little support for the hypothesis that suitability for rain-fed agriculture has effects on democratic outcomes today that are independent of the effects of Arab conquest.

\section{II.D. Desert Terrain as an Instrument for Arab Conquest}

If desert terrain affects democratic outcomes today only through the institutional developments that followed Arab conquest, then desert terrain should be a valid instrument for Arab conquest in equation 1. Table 5 pre- 
sents results of instrumental variables (IV) regressions in which I instrument for Arab conquest using annual rainfall as the measure of desert terrain. (Results using, alternatively, the percentage of a country covered by desert terrain are not reported here but are qualitatively identical.) I present these IV results for two reasons. First, if Arab conquest is a noisy measure of treatment with the relevant historical institutions, the IV results can help address biases caused by this measurement error. Second, overidentification tests provide an additional test of the hypothesis that desert terrain influences democratic outcomes today only through Arab conquest.

Why do I expect desert terrain and Arab conquest to be statistically related? It is well known that Arab armies had significant military advantages in areas dominated by desert terrain. Bernard Lewis sums up this point by noting that "the strategy employed by the Arabs in the great campaigns of conquest was determined by the use of desert-power. . . the desert was familiar and accessible to the Arabs and not to their enemies" (Lewis 1993a, p. 54). Similarly, Hugh Kennedy (2007, p. 371) notes that bedouin armies were particularly able in the "barren and inhospitable" milieus that constituted much of the territory conquered by Arab armies, and Donald Hill (1975) suggests that the Arab use of the camel greatly facilitated conquest on or near desert terrain. Consequently, areas with desert terrain were more likely to be selected into treatment with the relevant institutional framework. ${ }^{10}$

Table 5 presents the relevant results. The top panel presents the IV (twostage least squares) estimates, the second panel the first-stage results for Arab conquest, the third panel the ordinary least squares results, and the bottom panel the $p$ values from the appropriate overidentification tests where relevant. The first three columns use the entire sample, and the final three columns limit the sample to countries with Muslim majorities.

In columns 5-1 and 5-4, I instrument for Arab conquest with the distance of the geographical center of a country (its centroid) from Mecca. The results in the second panel show a strong first-stage relationship between distance from Mecca and Arab conquest. In both specifications the point estimates and the standard errors on Arab conquest roughly double when compared with the ordinary least squares results.

In columns 5-2 and 5-5, I instrument for Arab conquest using the logarithm of a country's annual rainfall. The first-stage results again show a strong relationship. In columns 5-3 and 5-6, I instrument for Arab conquest

10. See Michalopoulos, Naghavi, and Prarolo (2010) for a related discussion of how desert terrain and unequal agricultural endowments may have affected this selection. 
using both distance from Mecca and the logarithm of annual rainfall. The overidentification tests for these two regressions are useful since they are a direct test of the exclusion restriction that annual rainfall affects democratic outcomes today only through Arab conquest. Although such tests may not lead to a rejection if the two instruments are invalid but still highly correlated with each other (and thus the tests should be treated with some caution), the data support the exclusion restriction implied by my approach. Thus, the evidence is consistent with the claim that desert terrain affects democratic outcomes today through institutions developed following Arab conquest and not through channels unrelated to Arab conquest. ${ }^{11}$

\section{The Institutional Persistence Hypothesis}

The institutional persistence hypothesis attributes the Arab League's democratic deficit today to the long-term influence of the control structures developed in the centuries following the Arab conquests. The view that the region has a propensity toward autocratic institutions that is rooted in historical events goes back at least to Montesquieu (1989 [1748]) and was echoed by prominent Arab thinkers in the 19th century (Hourani 1962). Following decolonization, many saw the failure of the parliamentary democratic form of government as a legacy of the region's historical institutional framework (Issawi 1956). More recently, scholars such as Lewis (1993b) and Elie Kedourie (1994) have emphasized that a unique set of institutions developed in the areas conquered by Arab armies and that these historical institutions have had enduring effects. This framework was characterized both by the widespread use of slave armies (Blaydes and Chaney 2011), as noted above, and by the emergence of religious leaders as the primary check on the power of the sovereign (Chaney 2011).

\section{III.A. The Institutions of the Medieval Islamic World}

The introduction of slave armies across the region starting in the 9th century CE has been called "a major innovation in Middle Eastern history" (Lapidus 2002, p. 104) and is thought to have led to "vast changes in the organization of society ... everywhere the old landowning and bureaucratic elites lost their authority and were replaced by nomadic chieftains and slave soldiers" (Lapidus 2002, pp. 108, 114). As these elites lost political power, this power became increasingly concentrated in the hands of rul-

11. In this sense, the results complement recent studies that find that geography influences present-day outcomes through historical events (for example, Nunn and Puga 2012). 
ers backed by slave soldiers and the religious leaders who emerged as the primary check on their power (Chaney 2011, 2012, Hodgson 1974, p. 131).

The historical division of power between the military (the sovereign backed by his army of slaves) and religious leaders did not produce democratic institutions. Instead, both religious and military elites worked together to develop and perpetuate a "classical" institutional equilibrium. This institutional framework, often referred to as Islamic law, seems to have been designed with the interest of both groups of leaders in mind (Kuran 2011, Chaney 2012). Although religious leaders also devised "equilibrium institutions" to protect the interests of the general population to a degree, both the military and the religious elites worked to resist the emergence of rival centers of political power, such as merchant guilds, that could have facilitated institutional change.

Comparison with the historical evolution of Western Europe suggests that the widespread use of slave armies was a key innovation that hindered the development of civil society (that is, the emergence of a plurality of groups with both political power and conflicting interests) in the regions conquered by Arab armies. In Western Europe a series of military shocks between the 5th and the 7th centuries CE greatly altered the late-Roman political equilibrium, which seems to have had many similarities with the equilibrium that emerged in the Islamic world (Bloch 1961, p. xviii, Chaney 2012). These military shocks led rulers to remunerate their forces with land grants. The long-lived nature of these shocks meant that military forces led by local, landowning nobles increasingly became independent of central authority. Over time they emerged as a landed aristocracy that served as an independent interest group. The emergence of this group led to a separation of powers among the landed aristocracy, the clergy, and the sovereign (Chaney 2012).

The emergence in Western Europe of a landed aristocracy with an independent power base led to competition and at times open conflict among members of the clergy, the aristocracy, and the sovereign. This fracturing of political power facilitated the development of civil society by allowing other, less powerful groups to leverage one powerful group against another. For example, Henri Pirenne, a renowed Belgian historian, suggests that the conflicting interests of these three power centers aided merchant groups in their quest for greater independence (see Pirenne 1946 [1925], chapter 7, for a detailed discussion). Chaney (2012) suggests that this fracturing of political power may have also increased the efficacy of the legal system, facilitated the emergence of the Catholic Church as an independent institution, and led to the development of medieval parliaments. In other words, 
a more diffuse distribution of political power encouraged the further development of civil society.

In areas conquered by Arab armies, by contrast, the use of slave armies meant that military power remained concentrated in the hands of the sovereign. This prevented the emergence of a European-style landed aristocracy and the concomitant development of civil society. Patricia Crone, a prominent scholar of Islamic history, stresses the role slave armies played in weakening existing power groups. She views the introduction of slave armies as an attempt by the ruler "to make himself independent of other wielders of power" (Crone 2005, p. 88). Crone (1999, p. 326) also provides an explanation for why the Islamic world did not follow the path of Western Europe. She suggests that rulers in the Islamic world did not experience the series of military and financial shocks that occurred in Europe and were thus able to avoid the emergence of a landed aristocracy, since they did not need to fund their armies by giving land grants to local nobles. Lisa Blaydes and Chaney (2011) provide evidence consistent with this hypothesis.

Regardless of why slave armies emerged and were widely used in the areas conquered by Arab armies, the evidence suggests that following this development, military and religious leaders worked together to discourage the emergence of groups that could have facilitated the development of civil society (see, for example, Lapidus 1984, pp. 103-04). Indeed, the coalition between slave army-backed rulers and religious leaders seems to have been quite successful at eliminating rival groups (Lapidus 2002, pp. 114, 116). Unlike the elites they replaced, the slave armies lacked connections to the native populations and thus did not serve as a separate interest group that could help check the sovereign's power.

\section{III.B. Persistence and Long-Term Effects of the "Classical" Framework}

The division of political power in the Arab conquest regions between rulers backed by slaves and religious elites proved remarkably enduring. For example, although Egypt was conquered by the Ottoman Empire in $1517 \mathrm{CE}$, remnants of the local elite eventually reestablished themselves and continued to rely on slave armies to support their positions until the arrival of Napoleon in $1798 \mathrm{CE}$. Outside of Egypt, local rulers also relied on slave soldiers in the Ottoman domains that had been conquered by Arab armies (Hathaway and Barbir 2008, pp. 98-99)..$^{12}$ Importantly,

12. On the use of slave armies in the Safavid Empire (which included modern-day Iran), see Lockhart (1959). 
in regions first incorporated into the Muslim world under the Ottomans (such as the Balkans), it seems that local elites remained in power and perpetuated previous institutional arrangements (Lapidus 2002, p. 202). Similarly, where Islam spread by conversion (for example, to Indonesia, Malaysia, and sub-Saharan Africa) rather than by conquest, institutions were shaped "by a local elite which preserved its political and cultural continuity" (Lapidus 2002, p. 203). Consequently, an institutional divide arose within the Muslim world between areas that had been incorporated early, by Arab conquest, and those that were incorporated later, by other means.

By the 19th century the political equilibrium in the Arab conquest regions had begun to undergo substantial transformations, but from a base of both weak institutions and weak civil societies. For example, local populations had largely been excluded from both military service and governing for centuries. One historian highlights this historical legacy in Tunisia when describing the conscription of native peasants into the armed forces for the first time in the 19th century: "conscripting peasants into the armed forces introduced the hitherto unheard-of notion that native Tunisians ... might play a role in the governance of the country" (Perkins 2008, p. 17).

Over the next century, European colonizers and native rulers seem to have worked to perpetuate the historical concentration of political power by keeping civil societies weak and blocking the emergence of rival groups. This point is stressed by Lewis (1993b, p. 96), who notes that "modernization in the nineteenth century, and still more in the twentieth, far from reducing this [historical] autocracy, substantially increased it."

Consequently, when many of the Arab conquest areas gained independence after World War II, the new states inherited both weak institutions and weak civil societies. Consistent with the framework developed by Daron Acemoglu, James Robinson, and Thierry Verdier (2004), kleptocratic regimes emerged across the region (Brownlee 2002) and worked to keep civil societies weak and political power concentrated. In this environment, religious leaders have again emerged as the primary check on the power of the military in many areas (al-Sayyid Marsot 1984). Thus, the distribution of political power in some areas today bears a striking resemblance to its historical distribution. Contemporary observers have noted these similarities, and some Arab critics have "called their rulers Mamelukes, alluding to the slave-soldiers who exercised unrestrained and arbitrary power in those countries" (Kedourie 1994, p. 92). Amira Sonbol (2000, p. xxvi) similarly 
notes that in Egypt "the military practice[s] prerogatives similar to those enjoyed by the [slave soldiers]."

\section{III.C. Government Share of GDP, Access to Credit, Trade Unions, and Arab Conquest}

Does the institutional persistence hypothesis account for the empirical patterns presented above? In this section I explore this question by examining the channels through which Arab conquest may continue to affect political outcomes today. I view this analysis as preliminary and exploratory, as data limitations make it difficult to pin down the precise channels underlying the observed empirical patterns with any reasonable degree of certainty. Instead, I examine the extent to which the available data are consistent with the historical evidence presented in sections III.A and III.B.

The main predictions of the institutional persistence hypothesis as developed above are that political power should be abnormally concentrated in areas conquered by Arab armies and that civil societies in those areas should be unusually weak. Since I do not have direct measures of either the concentration of power or the strength of civil society, I instead use as proxies the government share of GDP, the extent to which existing institutions facilitate access to credit, and the number of trade unions normalized by GDP.

The logic behind the use of the government's share of GDP is rooted in the region's economic development over the past 60 years. As noted above, after the end of the colonial era, governments in the Arab conquest areas worked to impede the emergence of autonomous social groups. For example, the state stymied the emergence of politically powerful merchant groups (Malik and Awadallah 2011). As a consequence, government today should be directly involved in an abnormally large share of economic production in these areas (Kuran 2011, p. 301).

Table 6 presents results on the empirical relevance of this prediction. Columns 6-1 through 6-3 report results from a regression similar to equation 1 but using the government's share of GDP in 2010 as the dependent variable. Column 6-1 shows that countries conquered by Arab armies have government GDP shares that are 7 percentage points higher on average than in those not conquered. Column 6-2 shows that this result is not driven by the region's democratic deficit. Column 6-3 shows that despite little evidence that Arab League countries are different from non-Arab League countries, the results on the Arab conquest variable lose statistical significance when one introduces an Arab League dummy. 


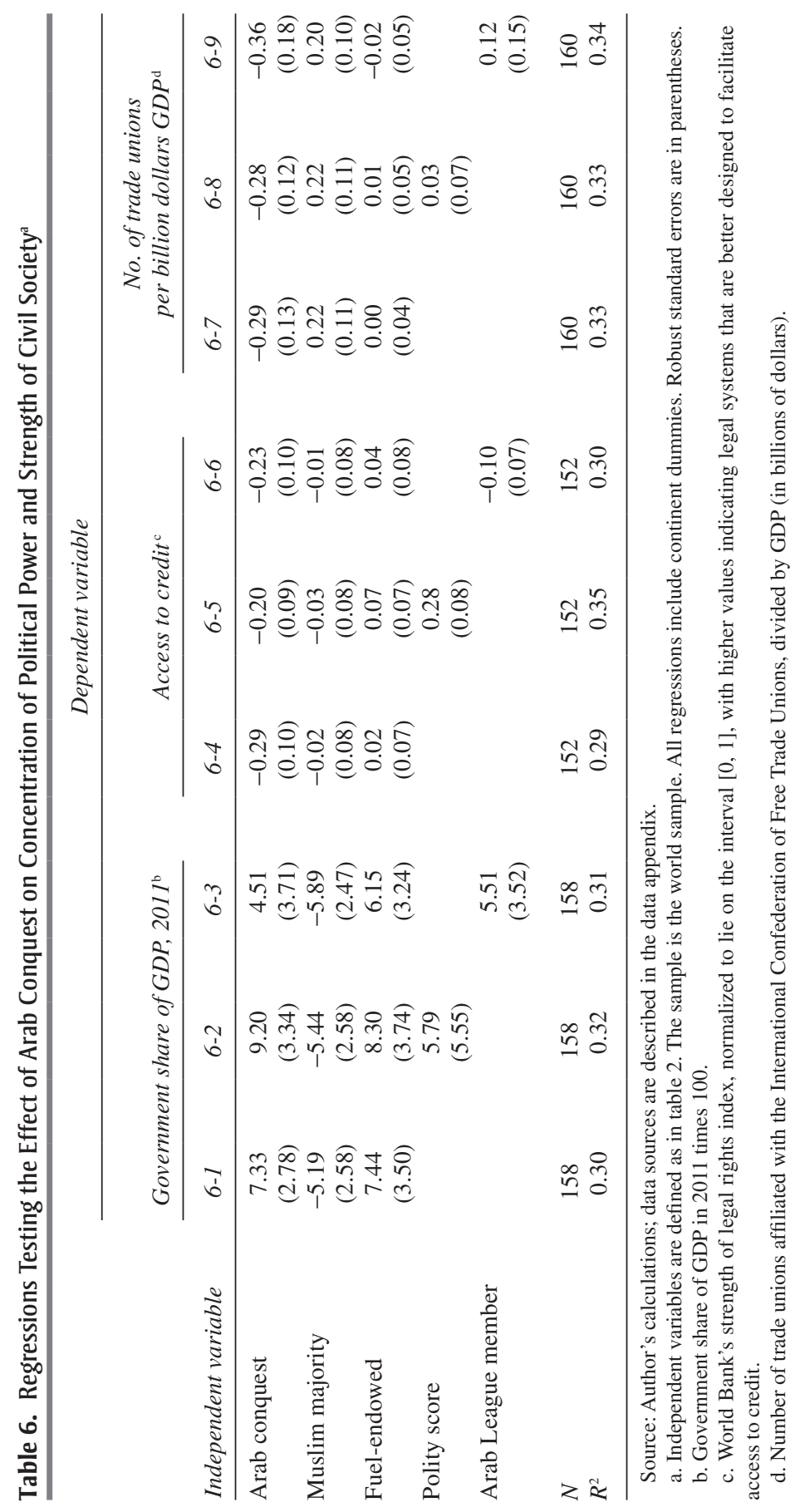


Columns 6-4 through 6-6 examine the extent to which governments in the Arab conquest areas continue to resist the development of autonomous social groups today. Here I use the World Bank's "Strength of Legal Rights Index" as the dependent variable. I normalize this index to range from 0 to 1 , with higher scores indicating that the legal system is better designed to expand access to credit. I expect the legal system in countries conquered by Arab armies to be inimical to the expansion of credit, since the region's historical institutions have both endowed ruling elites with unusual levels of political power and left civil society groups such as merchants abnormally weak. The results are consistent with this prediction: the legal systems in countries that were conquered by Arab armies are between 0.20 and 0.29 point (roughly 1 standard deviation) less hospitable to the expansion of credit than the average legal system elsewhere.

Finally, columns 6-7 through 6-9 report results using as the dependent variable the number of trade unions in a country that are affiliated with the International Confederation of Free Trade Unions, divided by GDP (in billions of dollars). The point estimates on the Arab conquest variable show that areas conquered by Arab armies have between 0.28 and 0.36 (just over 1 standard deviation) fewer trade unions per billion dollars of GDP. These results do not seem to be driven either by the region's democratic deficit or by membership in the Arab League. They are, however, consistent with the prediction that civil societies are abnormally weak in Arab conquest areas.

In sum, although it is difficult to measure the extent to which political power is abnormally concentrated and civil societies are weak in areas conquered by Arab armies, the evidence in this subsection is largely consistent with this prediction.

\section{The Arab Spring: Past as Prologue?}

The findings presented in this paper suggest that the democratic deficit in the Arab League on the eve of the Arab Spring had deep historical roots. However, this result does not imply that the Arab Spring will not lead to sustained democratic change. Indeed, the numerous structural changes in the Arab world over the past decades (Rauch and Kostyshak 2009) may have helped to lessen the weight of history, rendering many Arab states fertile ground for sustained democratic change today.

\section{IV.A. The Determinants of the Uprisings}

One prominent model of democratic change links economic downturns and popular discontent with democratizations (Acemoglu and Robinson 
Table 7. Correlates of Unrest in the Arab League ${ }^{a}$

\begin{tabular}{|c|c|c|c|c|c|}
\hline & \multicolumn{5}{|c|}{ Independent variable } \\
\hline & Thriving ${ }^{\mathrm{b}}$ & $\begin{array}{c}\text { Discontented } \\
\text { youth }^{\mathrm{c}}\end{array}$ & Unemployment $^{\mathrm{d}}$ & $\begin{array}{c}\text { Change in } \\
\text { fertility rate, } \\
1980-2010^{\mathrm{e}}\end{array}$ & $\begin{array}{c}\text { Fertility rate }, \\
2010\end{array}$ \\
\hline $\begin{array}{l}\text { Regression } \\
\text { coefficient }\end{array}$ & $\begin{array}{c}-0.97 \\
(0.43)\end{array}$ & $\begin{array}{c}-0.12 \\
(0.51)\end{array}$ & $\begin{array}{c}-2.33 \\
(1.24)\end{array}$ & $\begin{array}{l}-0.21 \\
(0.22)\end{array}$ & $\begin{array}{c}-0.06 \\
(0.08)\end{array}$ \\
\hline$N$ & 20 & 17 & 20 & 20 & 21 \\
\hline$R^{2}$ & 0.11 & 0.00 & 0.09 & 0.03 & 0.03 \\
\hline
\end{tabular}

Source: Author's calculations; data sources are described in the data appendix.

a. The dependent variable is an indicator variable equal to 1 if the country experienced unrest in 2011 . The sample consists of Arab League member countries. Robust standard errors are in parentheses.

b. Percentage of the country's population in 2010 that were self-reportedly "thriving" as defined in the Gallup World Poll.

c. Average percentage of the country's population in 2010 who answered no to the following question in the Gallup World Poll: "Would you say that the leadership of [country name] maximize on the potential of youth?"

d. Average unemployment rate in the country in 2010.

e. Logarithm of the 2010 fertility rate minus the logarithm of the 1980 fertility rate.

2006). ${ }^{13}$ To investigate the catalysts behind the recent uprisings, I limit the sample to the member states of the Arab League and estimate the following linear probability model:

$$
\text { Uprising }_{i}=\beta_{0}+\beta_{1} X_{i}^{2010}+\varepsilon_{i},
$$

where Uprising $i$ is an indicator variable equal to 1 if country $i$ experienced an uprising in 2011 (that is, if the country is Bahrain, Egypt, Libya, Syria, Tunisia, or Yemen), and $X^{2010}$ is the variable of interest measured in 2010.

The first column of table 7 regresses Uprising $_{i}$ on the mean number of respondents in a country who were self-reportedly "thriving" in the Gallup World Poll. This variable is normalized to lie on the interval $[0,1]$, where higher values denote greater self-reported well-being. The results show that a 0.1 increase in this variable in 2010 is associated with a decrease in the probability of an uprising in 2011 of roughly 10 percentage points and is statistically significant. The remaining columns regress Uprising $_{i}$ on a variety of other variables that have been suggested as catalysts for the uprisings. The results show that these variables - the discontent of the youth population, the unemployment level, changes in fertility between 1980 and

13. For a recent empirical investigation of this hypothesis, see Brückner and Ciccone (2011). 
Table 8. Self-Reported Well-Being and Support for Sharia in Arab League Countries ${ }^{\mathrm{a}}$

\begin{tabular}{|c|c|c|c|c|}
\hline \multirow[b]{2}{*}{ Country } & \multicolumn{3}{|c|}{ Percent thriving ${ }^{\mathrm{b}}$} & \multirow[b]{2}{*}{ Percent supporting sharia } \\
\hline & 2009 & 2010 & 2011 & \\
\hline Somalia & 18.25 & 12.47 & 6.51 & 75.37 \\
\hline Saudi Arabia & 37.73 & 44.56 & 51.57 & 71.62 \\
\hline Egypt & 13.80 & 11.64 & 9.13 & 71.15 \\
\hline Qatar & 48.87 & 55.70 & 51.35 & 69.87 \\
\hline Yemen & 17.81 & 13.04 & 10.22 & 66.07 \\
\hline Jordan & 34.50 & 30.43 & 27.12 & 64.10 \\
\hline U.A.E. & 52.30 & 56.27 & 60.94 & 56.79 \\
\hline Palestine & 13.90 & 16.25 & 16.26 & 51.27 \\
\hline Djibouti & 11.59 & 18.97 & 14.56 & 47.37 \\
\hline Kuwait & 46.29 & 47.03 & 50.70 & 45.99 \\
\hline Comoros & 3.19 & 4.32 & 4.46 & 42.13 \\
\hline Libya & 24.11 & 14.17 & n.a. & 41.93 \\
\hline Algeria & 21.97 & 20.99 & 20.00 & 37.51 \\
\hline Mauritania & 6.99 & 13.35 & 18.11 & 36.19 \\
\hline Iraq & 9.80 & 13.70 & 14.15 & 34.98 \\
\hline Morocco & 13.80 & 11.99 & 16.52 & 32.58 \\
\hline Syria & 22.64 & 6.27 & 2.98 & 29.49 \\
\hline Tunisia & 16.32 & 14.23 & 17.12 & 25.51 \\
\hline Sudan & 10.46 & 11.05 & 10.53 & 21.00 \\
\hline Lebanon & 24.39 & 22.76 & 18.63 & 13.94 \\
\hline Bahrain & 38.67 & 28.69 & 8.19 & n.a. \\
\hline Oman & n.a. & n.a. & 52.17 & n.a. \\
\hline Turkey & 13.27 & 16.57 & n.a. & 10.05 \\
\hline
\end{tabular}

Source: Gallup World Poll.

a. Countries are listed in descending order of popular support for implementing sharia; italics indicate countries that experienced uprisings in 2011. Data for Turkey, a non-Arab League country, are included for comparison.

b. Percentage of the country's population in the indicated year that were self-reportedly "thriving" as that term is defined in the Gallup World Poll.

c. Average proportion of the population between 2005 and 2011 answering in the Gallup World Poll that "Sharia must be the only source of legislation" in response to the following question: "Sharia is an Arabic word which means Islam's religious principles. In general, which of these statements comes closest to your own point of view?"

2010 , and the fertility level in 2010 - have little power in predicting which countries experienced uprisings in 2011.

Although the small sample sizes suggest caution when interpreting these results, it is interesting that the level of self-reported well-being in 2010 is the only variable that predicts unrest in 2011 from a statistical standpoint. This result suggests that the level of subjective well-being in 2011 may help predict the propensity for further unrest across the Arab League. For this reason, the first three columns of table 8 detail the evolution of self-reported well-being in the Arab world in 2009, 2010, and 
2011 using Gallup World Poll data. The table reports for each country the mean number of respondents who were self-reportedly "thriving" in each of those three years.

The results suggest that oil-rich Gulf countries such as Kuwait, Saudi Arabia, and the United Arab Emirates are unlikely to experience widespread unrest in the near future. However, the sharp drop in well-being in Bahrain between 2009 and 2011 from a relatively high base suggests that even countries with high self-reported well-being may be more susceptible to unrest than the results in table 7 indicate.

\section{IV.B. Democracy and Advances in Education}

The region's history suggests that popular uprisings leading to a regime change do not guarantee long-lasting democratic change. Have the numerous structural changes - in particular, the rise in average educational attainmentover the past decades helped lessen the weight of history, ensuring that the ultimate outcome of the recent wave of popular protest will be more democratic than the outcomes of popular uprisings in the past?

Space considerations limit the extent to which I am able to investigate the evolution of the many possibly relevant indicators in the Arab League over the past several decades. Instead, in this section I detail the evolution of average education in the region over the past 60 years. I concentrate on this indicator because a large literature views high average educational attainment as a prerequisite for democracy. ${ }^{14}$ Figure 5 traces average years of education since 1950 for three groups of countries: non-Muslim developing countries; Muslim, non-Arab conquest countries; and countries that were conquered by Arab armies. The figure shows the tremendous increases in average education over the past 60 years in the countries conquered by Arab armies. Although differences in education do not explain the democratic deficit from a statistical standpoint in these countries, their educational attainment has largely converged to the non-Arab conquest Muslim average. ${ }^{15}$

What do such structural changes imply for the future of democracy in the Arab world? Again, data limitations prevent a systematic investigation of the channels through which history continues to affect democratic

14. See Acemoglu and others (2005) for an overview of this literature and Glaeser, Ponzetto, and Shleifer (2007) for one causal mechanism through which higher levels of education may lead to more-democratic outcomes.

15. In a recent working paper, Campante and Chor (2011) argue that such structural changes have made political protests more likely and pressures for democratization more acute. 
Figure 5. Educational Attainment in Arab Conquest and Non-Arab Conquest Countries, 1950-2010

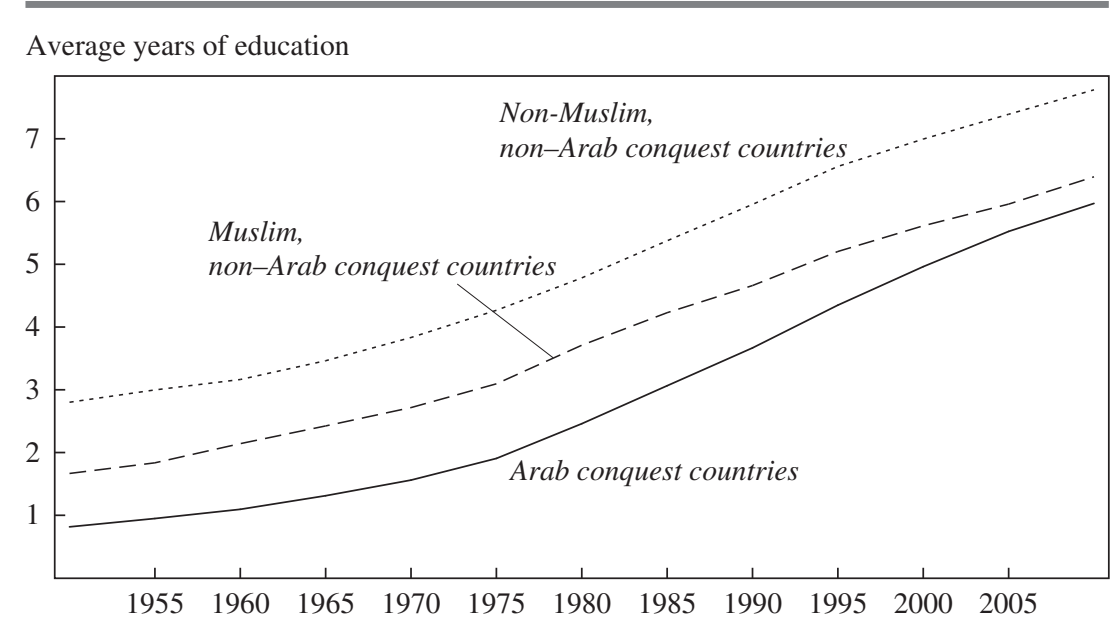

Source: Barro-Lee data set (Barro and Lee 2010).

outcomes today, so it is hard to know the extent to which these changes have helped to remove the historical impediments to democratic change. However, if the literature stressing the importance of education for democratization is correct, the large increases in education in the Arab conquest countries over the last 60 years suggest that the prospects for democracy in the region are brighter today than at any time in its history.

\section{IV.C. A Democratic Dawn?}

At some level it is obvious that the structural changes the region has undergone over the past 60 years have made the Arab world more fertile ground for sustained democratic change today than at any time in the past. For example, the widespread protests that swept across the region in 2011 have no precedent in the region's history. However, the political equilibrium in many states in the Arab League continues to resemble the equilibrium that has accompanied autocratic institutions for centuries, with political power concentrated in the hands of military and religious leaders.

The region's institutional history suggests that democratic change is less likely where political power remains concentrated in such a manner. Although I do not observe the extent to which political power is concentrated in the hands of military and religious leaders, I do observe popular support for the implementation of sharia, or Islamic law. To the extent that 
religious leaders derive political power from popular support, support for the implementation of sharia may be a good proxy for the relative power of religious leaders across countries. Thus, I use popular support for sharia as a measure of the extent to which political power remains concentrated in the hands of religious leaders across the Arab world today. ${ }^{16}$

The final column of table 8 reports average support for sharia over 2005-10 in each of the member states of the Arab League. Countries that experienced unrest in 2011 are highlighted. The results show that in countries such as Egypt and Yemen, popular support for sharia is high, whereas in countries such as Syria and Tunisia it is much lower. However, with the exception of Lebanon, nowhere in the Arab League does support for sharia approach the low level observed in Turkey, which is widely seen as a democratic model for the region. Inasmuch as higher support for sharia is indicative of increased concentration of political power, these results, combined with the historical evidence, suggest that long-lasting democratic institutions are more likely to emerge in countries such as Tunisia than in others such as Egypt or Yemen.

\section{Conclusion}

In this paper I have provided evidence suggesting that the Arab League's democratic deficit on the eve of the Arab Spring had deep historical roots. These results cast doubt on claims that Muslim theology, Arab culture, or the Arab-Israeli conflict is a systematic obstacle to democratic change. Instead, the available evidence suggests that the region's democratic deficit is a product of the long-run influence of control structures developed under Islamic empires in the premodern era.

Will the Arab Spring end the region's long history of autocratic rule and usher in long-lasting democratic change? Unfortunately, data limitations prohibit a detailed investigation of the channels through which the region's historical institutional equilibrium continues to affect outcomes today. Consequently, I am unable to measure the extent to which these channels affect current political developments.

Despite these limitations, at some level the structural changes that the region has undergone over the past decades have made the Arab world

16. The use of this metric is supported by recent election results in Tunisia and Egypt. Although Islamist parties won majorities in both countries, these groups seem on the whole less moderate and to wield more political power in Egypt than in Tunisia. This is consistent with the results presented in table 8 showing that a larger share of the populace support implementation of sharia in Egypt than in Tunisia. 
more fertile ground for sustained democratic change today than at any time in the past. That said, in some countries of the Arab world (such as Egypt and Yemen) the present-day political equilibrium seems more similar to the historical equilibrium that has accompanied autocratic institutions for centuries than in others (such as Tunisia). In this sense, history suggests that democracy is less likely to emerge in the former group of countries than in the latter.

What, then, are the implications of the preceding analysis in the current policy environment? Although the results suggest that the Arab League's democratic deficit on the eve of the Arab Spring has deep historical roots, this deficit does not appear to be rooted in religious beliefs. However, the region's institutional history shows that overwhelming popular support for Islamist groups may undermine democratic efforts by concentrating political power in the hands of these groups. Indeed, the recent past shows that Islamists are just as likely as other groups to establish autocratic rule in the absence of checks on their power. Thus, unless other interest groups, such as labor unions or commercial interests, check their power, Islamists may replace secular rulers and usher in a new wave of autocracy in some Arab countries.

In closing, it should be stressed that these conclusions are largely based on an implicit model of the region's institutional history. Although this conceptual framework might be consistent with the available data and may help explain the past, if there has been a regime shift (statistically speaking), predictions based on this framework will be poor. Thus, there are many reasons to be cautious about using the evidence available today regarding democratic change in the Arab world as a guide for future policy decisions.

\section{DATA APPENDIX}

Baseline Data Set: Country Boundaries, Polity and Freedom House Scores My main measure of the extent to which countries are democratic comes from the Polity IV Project (www.systemicpeace.org/polity/polity4.htm). I use the polity 2 variable, which ranks countries on a scale that ranges from "strongly autocratic" at -10 to "strongly democratic" at +10 . I start with the 162 countries that have nonmissing polity scores in 2010 and then merge in the Arab conquest variable, calculated in ArcGIS using the world country boundaries in January 2008 as provided in the shapefile "World Countries 2008: ESRI Data \& Maps 2008" (available at calvert.hul.harvard.edu). Since Kosovo and Timor Leste are not provided in the shapefile that I use, 
this leaves me with the 160 observations that I use in the baseline regressions throughout the paper. The 2010 Freedom House scores used in the paper are the overall freedom ratings from the Freedom in the World report (www.freedomhouse.org/report/freedom-world/freedom-world-2010), collected for the same 160 countries.

Boundaries of the Islamic World The boundaries of the Muslim world in 1100 and 1900 CE are drawn from Kennedy (2002), section II.

Percent Muslim The percentage of a country's population that is Muslim is taken from the Pew Forum's "Mapping the Global Muslim Population" project (www.pewforum.org/Mapping-the-Global-Muslim-Population.aspx).

Percent Desert I calculate the percentage of a country's landmass covered by desert or barren terrain using the country-level statistics on the distribution of aggregate land cover classes from the Food and Agriculture Organization's Global Agro-Ecological Zones (GAEZ) 2002 database (www.iiasa.ac.at/Research/LUC/SAEZ/app/app01.htm).

Cereal Suitability I calculate the percentage of a country's landmass suitable for cereal production using the country-level statistics on gross extents with cultivation potential for intermediate input level rain-fed cereals from the FAO's GAEZ 2002 database. Following Nunn and Qian (2011), I define land to be suitable for cereal cultivation if it is classified in the database as being either "very suitable," "suitable," or "moderately suitable."

Years of Education Average years of education in a country is the educational attainment for the total population aged 25 and over, taken from the Barro-Lee data set (Barro and Lee 2010; www.barrolee.com).

Government Share of GDP Government expenditure in a country is taken from the CIA World Factbook (https://www.cia.gov/library/publications/ the-worldfactbook/fields/2056.html). The majority of these expenditure observations are from 2011. Each country's expenditure is calculated as a share of its 2011 GDP as reported in the CIA World Factbook (https://www. cia.gov/library/publications/the-world-factbook/fields/2195.html).

Women in National Parliament The percentage of a country's parliamentary seats (in the lower chamber only, if there are two) held by women in 2010 is determined from data in the World Bank's World Development Indicators (data.worldbank.org/indicator/SG.GEN.PARL.ZS).

Trade Unions The number of trade unions in a country that are affiliated with the International Confederation of Free Trade Unions (ICFTU), as determined from the list of affiliated trade unions at www.icftu.org/ addresslist.asp?Language=EN, is divided by the country's 2011 GDP (in billions of dollars) as reported in the CIA World Factbook. 
Alcohol Consumption Each country's total average alcohol consumption per capita, in liters of pure alcohol, is drawn from the World Health Organization's 2011 Global Status Report on Alcohol and Health (www. who.int/substance_abuse/publications/global_alcohol_report/en/).

Support for Implementation of Sharia This is the average proportion of the population between 2005 and 2011 answering in the Gallup World Poll that "Sharia must be the only source of legislation" in response to the following question: "Sharia is an Arabic word which means Islam's religious principles. In general, which of these statements comes closest to your own point of view?" (The other possible responses were "Sharia must be a source of legislation, but not the only source," and "Sharia should not be a source of legislation.")

Thriving In the Gallup World Poll, this metric "measures respondents' perceptions of where they stand, now and in the future." Building on earlier work by Hadley Cantril and The Cantril Self-Anchoring Striving Scale, Gallup measures life satisfaction by asking respondents to rate the status of their lives on a "ladder" scale with steps numbered from 0 to 10 , where 0 indicates the worst possible life and 10 the best possible life. Individuals who rate their current lives a 7 or higher and their future an 8 or higher are described as "thriving" (Gallup 2011, p. 43). I calculate the percentage of the population that are thriving within a country each year.

Religiosity I calculate the country average of the religiosity index in the Gallup World Poll between 2005 and 2011. This index is described as "a measure of the importance of religion in respondents' lives" and ranges from 0 to 100 (where higher values indicate more religiosity). The index averages scores from the following questions: "Is religion an important part of your daily life?" "Have you attended a place of worship or religious service within the last seven days?" and "In [country name], do you have confidence in each of the following or not? How about religious organizations (churches, mosques, temples, etc.)?" Index scores are calculated at the individual record level. For each individual record, positive answers are scored as a 1 and all other answers as 0 . The record's final index score is the mean of the three scores multiplied by 100 (Gallup 2011, p. 57). I take the mean of this metric by country divided by 100 .

Unemployment I use the variable EMP_UNEMP in the Gallup World Poll. This is the "percentage of respondents in the workforce who are not employed, who have been actively looking for work within the last four weeks, AND who say they would have been able to begin work in the last four weeks." This measure is comparable to those used by the Bureau of 
Labor Statistics and the International Labour Organization in their calculations of unemployment rates (Gallup 2011, p. 12).

Discontented Youth This is the average proportion of a country's population in 2010 answering no to the following question in the Gallup World Poll: "Would you say that the leadership in [country] maximize on the potential of youth?"

Fertility Rate I use the 2010 fertility rate for each country as reported in the World Bank's World Development Indicators, which "represents the number of children that would be born to a woman if she were to live to the end of her childbearing years and bear children in accordance with current age-specific fertility rates" (data.worldbank.org/indicator/SP.DYN.TFRT. IN/countries). I calculate the difference in fertility rates between 2010 and 1980 as the logarithm of the fertility rate in 2010 minus the logarithm of the rate in 1980 .

Access to Credit This is the World Bank's Strength of Legal Rights Index normalized to lie on the interval $[0,1]$, where "higher scores indicat[e] that these laws are better designed to expand access to credit" (data.worldbank. org/indicator/IC.LGL.CRED.XQ).

Rainfall I follow Haber and Menaldo (2010) and use the 2008 average precipitation in depth (millimeters per year) as reported in the World Bank's World Development Indicators (data.worldbank.org/indicator/ AG.LND.PRCP.MM). This metric is defined as "the long-term average in depth (over space and time) of annual precipitation in the country." Precipitation is defined as "any kind of water that falls from clouds as a liquid or a solid."

ACKNOWLEDGMENTS I thank George Akerlof, Pol Antràs, Lisa Blaydes, J. Bradford DeLong, Edward Glaeser, Nathan Nunn, Elias Papaioannou, Andrei Shleifer, the editors, and seminar participants for helpful discussions and comments. I also thank Gallup for sharing their data. Any remaining errors are mine. 


\section{References}

Acemoglu, Daron, and James A. Robinson. 2006. Economic Origins of Dictatorship and Democracy. Cambridge University Press.

Acemoglu, Daron, Simon Johnson, and James A. Robinson. 2001. "The Colonial Origins of Comparative Development: An Empirical Investigation." American Economic Review 91, no. 5: 1369-1401.

2002. "Reversal of Fortune: Geography and Institutions in the Making of the Modern World Income Distribution." Quarterly Journal of Economics 117, no. 4: 1231-94.

Acemoglu, Daron, James A. Robinson, and Thierry Verdier. 2004. "Kleptocracy and Divide-and-Rule: A Model of Personal Rule." Journal of the European Economic Association 2, no. 2-3: 162-92.

Acemoglu, Daron, Simon Johnson, James A. Robinson, and Pierre Yared. 2005. "From Education to Democracy?" American Economic Review 95, no. 2: 44-49.

Barro, Robert, and Jong-Wha Lee. 2010. "A New Data Set of Educational Attainment in the World, 1950-2010.” Working Paper no. 15902. Cambridge, Mass: National Bureau of Economic Research (April).

Blaydes, Lisa, and Eric Chaney. 2011. "The Feudal Revolution and Europe's Rise: Institutional Divergence in the Christian and Muslim Worlds before 1500 CE." Stanford University and Harvard University.

Bloch, Marc. 1961. Feudal Society: The Growth of Ties of Dependence. University of Chicago Press.

Brownlee, Jason M. 2002. "Low Tide after the Third Wave: Exploring Politics under Authoritarianism." Comparative Politics 34, no. 4: 477-98.

Brückner, Markus, and Antonio Ciccone. 2011. "Rain and the Democratic Window of Opportunity." Econometrica 79, no. 3: 923-47.

Campante, Filipe R., and Davin Chor. 2011. "'The People Want the Fall of the Regime': Schooling, Political Protest, and the Economy." Faculty Research Working Paper Series no. RWP11-018. Kennedy School of Government, Harvard University.

Chaney, Eric. 2011. "Revolt on the Nile: Economic Shocks, Religion and Political Power." Harvard University.

- 2012. "Separation of Powers and the Medieval Roots of Institutional Divergence between Europe and the Islamic Middle East." Harvard University.

Crone, Patricia. 1999. "The Early Islamic World." In War and Society in the Ancient and Medieval Worlds, edited by Kurt Raaflaub and Nathan Rosenstein. Harvard University Press.

- 2005. Medieval Islamic Political Thought. Edinburgh University Press.

Dell, Melissa. 2010. “The Persistent Effects of Peru's Mining Mita.” Econometrica 78, no. 6: 1863-1903.

Diamond, Larry. 2010. "Why Are There No Arab Democracies?" Journal of Democracy 21, no. 1: 93-104. 
Elbadawi, Ibrahim, and Samir Makdisi. 2007. "Explaining the Democratic Deficit in the Arab World." Quarterly Review of Economics and Finance 46 (2007): $813-31$.

Fish, M. Steven. 2002. "Islam and Authoritarianism." World Politics 55: 4-37.

Gallup. 2011. Worldwide Research Methodology and Codebook. Washington.

Glaeser, Edward, Giacomo Ponzetto, and Andrei Shleifer. 2007. "Why Does Democracy Need Education?" Journal of Economic Growth 12: 77-99.

Haber, Stephen, and Victor Menaldo. 2010. "Rainfall and Democracy." Paper presented at the Stanford Workshop in Comparative Politics, October 25.

_ 2011. "Rainfall, Human Capital, and Democracy." Stanford University and University of Washington.

Hathaway, Jane, and Karl K. Barbir. 2008. The Arab Lands under Ottoman Rule, 1516-1800. Harlow, England: Pearson Longman.

Hill, D. R. 1975. "The Role of the Camel and the Horse in the Early Arab Conquests." War, Technology and Society in the Middle East 32, no. 1: 32-43.

Hodgson, Marshall G. S. 1974. The Venture of Islam, Volume 2: The Expansion of Islam in the Middle Periods. University of Chicago Press.

Hourani, Albert. 1962. Arabic Thought in the Liberal Age. Oxford University Press.

Huntington, Samuel P. 1996. The Clash of Civilizations and the Remaking of World Order. New York: Simon \& Schuster.

Issawi, Charles. 1956. "Economic and Social Foundations of Democracy in the Middle East." International Affairs 32, no. 1: 27-42.

Jamal, Amaney A., and Mark Tessler. 2008. "Attitudes in the Arab World." Journal of Democracy 19, no. 1: 97-110.

Kedourie, Elie. 1994. Democracy and Arab Political Culture. Portland, Ore.: Frank Cass \& Co.

Kennedy, Hugh, ed. 2002. An Historical Atlas of Islam. Boston: Brill.

Kennedy, Hugh. 2007. The Great Arab Conquests: How the Spread of Islam Changed the World We Live In. London: Weidenfeld \& Nicolson.

Khashan, Hilal. 1998. "The Arab World's Travails: History's Burden.” Middle East Quarterly (March): 41-48.

Kuran, Timur. 2011. The Long Divergence: How Islamic Law Held Back the Middle East. Princeton University Press.

Lakoff, Sanford. 2004. "The Reality of Muslim Exceptionalism." Journal of Democracy 15, no. 4: 133-39.

Lapidus, Ira M. 1984. Muslim Cities in the Later Middle Ages. Cambridge University Press.

2002. A History of Islamic Societies. Cambridge University Press.

Lewis, Bernard. 1993a. The Arabs in History. Oxford University Press. 89-98.

Lockhart, Lawrence. 1959. "The Persian Army in the Safavid Period." Der Islam 34: 89-98. 
Malik, Adeel, and Bassem Awadallah. 2011. "The Economics of the Arab Spring." Working Paper WPS/2011-23. Oxford, England: Centre for the Study of African Economies.

Michalopoulos, Stelios, Alireza Naghavi, and Giovanni Prarolo. 2010. "Trade and Geography in the Economic Origins of Islam: Theory and Evidence." Nota di Lavoro no. 75.2010. Milan: Fondazione Eni Enrico Mattei.

Montesquieu, C. 1989 [1748]. The Spirit of the Laws. Cambridge University Press.

Noland, Marcus. 2008. "Explaining Middle Eastern Political Authoritarianism I: The Level of Democracy." Review of Middle East Economics and Finance 4, no. 1: 1-30.

Nunn, Nathan. 2008. "The Long-Term Effects of Africa's Slave Trades.” Quarterly Journal of Economics 123, no. 1: 139-76.

- 2009. "The Importance of History for Economic Development." Annual Review of Economics 1: 65-92.

Nunn, Nathan, and Diego Puga. 2012. "Ruggedness: The Blessing of Bad Geography in Africa." Review of Economics and Statistics 94, no. 1: 20-36.

Nunn, Nathan, and Nancy Qian. 2011. “The Potato's Contribution to Population and Urbanization: Evidence from a Historical Experiment." Quarterly Journal of Economics 126, no. 2: 593-650.

Perkins, Kenneth. 2004. A History of Modern Tunisia. Cambridge University Press.

Pirenne, H. 1946 [1925]. Medieval Cities: Their Origins and the Revival of Trade. Princeton University Press.

Rauch, James E., and Scott Kostyshak. 2009. "The Three Arab Worlds." Journal of Economic Perspectives 23, no. 2: 165-88.

Ross, Michael L. 2001. “Does Oil Hinder Democracy?” World Politics 53: 325-61.

Rowley, Charles K., and Nathanael Smith. 2009. "Islam's Democracy Paradox: Muslims Claim to Like Democracy, So Why Do They Have So Little?" Journal of Democracy 15, no. 4: 133-39.

Al-Sayyid Marsot, Afaf Lufti. 1984. "Religion or Opposition? Urban Protest Movements in Egypt." International Journal of Middle East Studies 16, no. 4: 541-52.

Sharabi, Hisham. 1988. Neopatriarchy: A Theory of Distorted Change in Arab Society. Oxford University Press.

Sonbol, A. 2000. The New Mamluks: Egyptian Society and Modern Feudalism. Syracuse University Press.

Stepan, Alfred, and Graeme B. Robertson. 2003. “An 'Arab' More Than 'Muslim' Electoral Gap.” Journal of Democracy 14, no. 3: 30-44. 


\section{Comments and Discussion}

\section{COMMENT BY}

GEORGE A. AKERLOF ${ }^{1}$ In this paper Eric Chaney has given some extremely clever arguments that the Arab conquests in the centuries after Muhammad and their long-term effects account for the low levels of democracy in Arab countries today. The paper is a tour de force. For the sake of brevity, I will forgo summarizing what he has done and will refrain from commenting on the econometrics.

Instead let me begin by trying on for size Chaney's view that the form of military organization in the areas of the Arab conquest had lasting effect. He places particular emphasis on the role of slave armies, with the religious authorities playing the role of legitimizing military rule as they also softened its roughest edges. Because of the slave armies, this military-clerical alliance did not need to compromise its authority to obtain outside support. Thus, the initial challenges that elsewhere would lead to democracy never took place in the Arab conquest areas.

If Chaney's story is broadly correct, it should not just explain how democracy has been thwarted in some countries. Like a photographic negative, it should also explain how democracy has emerged in others. The myth, and possibly the reality, of English history is that it all began at Runnymede, with the Magna Carta. The central government was weak because it needed the cooperation of its feuds to raise an army. That is the negative of the slave armies, as Chaney depicts them, following the Arab conquest. In England the king's need for the cooperation of those feuds meant they had to be given some protection against expropriation. This is perhaps the world's most famous foot in the door. It is consistent with Chaney's

1. The views in this comment are my own and do not necessarily reflect the views in any way of the International Monetary Fund. 
interpretation of what did not happen in the Arab conquest world that some three centuries later, Henry VIII, legitimated as he was outside of religion, could challenge the established church itself. And the resulting separation of church and state, we also know, was a further step in the emergence of democracy in England. This example of history outside the Arab conquest region gives us a non-Arab example of how the organization of the army could make a crucial difference in the decline in religious power and to the onset of democracy.

THE ARAB SPRING: WHERE DO WE GO FROM HERE? Let us then accept Chaney's hypothesis. But today - as after Runnymede—something new has entered the balance of power in the Arab conquest countries. Where do we go from here?

In general, what governments and elites can get away with relative to the general population largely depends on social norms as to what is considered legitimate or right for those authorities or elites to get away with. For most of history, most people have lived in exploitative regimes. The incentive system can be described as follows. If I do not obey the rules of the military, then some member of the military has a duty to punish me. If they do not punish me, then they have disobeyed the rules of the military, and they will be punished. If others do not punish them, they will be punished in turn. Thus, over a wide range of what I have called the rules of the military, everyone has an economic motivation to obey them. This obedience produces an equilibrium. And it describes how most political regimes have worked throughout human history. That is the equilibrium that Chaney is describing. It follows from Chaney's argument that the church-state alliance has played a major role in establishing that equilibrium. Why? Because as long as the church and the state were allied, the church would act as a bulwark, supporting and reinforcing the norms of the military-autocracy equilibrium. Not even a first step would be taken toward the emergence of democracy.

But the Arab Spring presents a challenge to those norms. Successful revolutions are not just about what is taught in the official histories. They are not just about kicking out the British, or the French, or the bad dictator. They are about changes in morality. In a successful revolution, people change their view of what is right and their duty to enforce it. When that happens, people are no longer willing to go along with the customs and rules of the military or the court kleptocracy. With the Arab Spring, the old incentives no longer worked. They no longer worked because people were willing to throw themselves in front of the bus. 
What we have seen in the Arab Spring, then, was a change in the view as to what those rules were. As a consequence, from now on every government in the region will have to pause before it acts, to think about whether its action is legitimate under the new rules. That is what happens in a successful revolution. For example, according to Gordon Wood (1992), the United States after 1776 had a social revolution. Men came to be addressed simply as "Mister," and women as "Mrs." or "Miss." The previous title of "gentleman" was given up. Similarly in the Indian independence movement, everyone was free to join Gandhi as he marched to the sea to manufacture salt and to challenge the British. The Arab Spring indicates just such a change, where people come to have a new conception of themselves.

It is useful to think about this in terms of economic growth. The Paul Romer view is that open societies have more growth because they have a greater influx of new ideas. We saw confirmation of that in the Soviet era, as the Soviet Union and the countries under its domination, which were closed to the rest of the world, lagged sadly behind.

The usual interpretation of openness is with respect to the outside world. But another type of openness is probably yet more important. Most societies and institutions have very proscriptive norms regarding who has the prerogative to speak and to think about various issues. People are, to varying degrees, outcast, not allowed to speak or to think. They are also remarkably passive in their acceptance of those roles. The American Revolution, and likewise the French Revolution, challenged those roles and empowered a much larger fraction of the population to think that their opinions were legitimate. In this way they opened up the sources of new ideas.

One role of the Arab Spring is to bring to the peoples of the Middle East and North Africa the same perception of themselves that came to Americans after the Revolution - that they are people who should, appropriately, have new ideas, and that their ideas should be taken seriously. They, too, should be called Mr. and Ms.

This, then, is the real promise of Arab Spring. There is further promise that once people have decided that, yes, they too are citizens, that yes, they are on an equal footing, then they and their ideas cannot be shoved back into the bottle. Revolutions, when successful, do not just replace bad government with good government. They turn everyone into a citizen. I cannot predict what will happen next in the region. But the Arab Spring is the necessary first step toward a more just society.

To conclude, Eric Chaney has written a very good paper. And it brings up larger questions regarding why the societies of the Middle East and 
North Africa have low levels of democracy. But it also indicates the nature of the fight for the people of this region to get a fairer shake than they have had in the past.

\section{REFERENCE FOR THE AKERLOF COMMENT}

Wood, Gordon S. 1992. The Radicalism of the American Revolution. New York: Knopf.

\section{COMMENT BY}

LISA BLAYDES Scholars have long been puzzled by the failure of countries in the Arab world to democratize. A number of explanations have been offered in the scholarly literature for the persistence of Arab autocracy, including the impact of Arab and Islamic culture (Kedourie 1992, Kramer 1993, Lewis 1993), the oil "curse" (Ross 2001, 2012), the region's desert geography (Haber and Menaldo 2010), and the patriarchal gender norms common in Arab society (Fish 2002). In this paper Eric Chaney provides a new explanation for the puzzle by focusing on the long historical shadow cast on countries that were conquered by Arab armies during the period of Islamic expansion before $1100 \mathrm{CE}$. Chaney finds that even after controlling for a country's Islamic heritage, legacy of Arab culture (as proxied by Arab League membership), and oil wealth, a history of Arab conquest is associated with a reduced probability of having more-democratic government in 2010.

Chaney's thesis represents a subtle, yet important, modification to existing arguments. Previous studies have identified a gap in democratic performance between Arab, Muslim-majority countries (which tend to be consistently undemocratic) and non-Arab, Muslim-majority countries (which tend to look quite similar to otherwise comparable countries). ${ }^{1}$ Chaney focuses instead on Arab conquest as an explanatory variable, arguing that areas that were conquered by the Arabs in Islam's expansion but either shed or never adopted the Arabic language (the key marker of Arab culture associated with Arab League membership) tend to be as undemocratic as their Arabic-speaking neighbors.

Chaney's paper challenges existing conceptualizations of the Arab democracy "deficit" by orienting the discussion away from such factors as the existence of a robust repressive apparatus (Bellin 2004, Diamond

1. See Stepan and Robertson (2003), Donno and Russett (2004), and Diamond (2010). 
2010), which are endogenous to historical patterns of political authority, or geopolitical factors like the Arab-Israeli conflict (Stepan and Robertson 2003, Diamond 2010), for which the intensity of the treatment varies both over time and across space in the region. Indeed, scholars who have sought to explain the Arab democracy deficit have long focused on explanatory variables so proximate that they are likely the product of longer-term political processes rather than the causes of contemporary forms of governance.

Although Chaney's explanation, I believe, correctly seeks to advance a narrative about "institutional persistence," the empirical relationship described in his cross-sectional analysis is not clear-cut. Chaney's analysis of the key correlation between Arab conquest and autocracy relies on the presence of a very small number of high-leverage countries that also tend to have small populations. Indeed, replicating Chaney's analysis with population-weighted regressions substantially attenuates the coefficient on the variable measuring Arab conquest and renders it statistically insignificant at conventional levels. Yet population-weighted regressions are justified in this case given that we want to understand the benefits of democratic governance as it affects individual citizens: should Turkey, with a population of 73 million living under relative democracy, be treated as empirically equivalent to Turkmenistan, with a population of 5 million living under autocracy?

From a theoretical perspective, the link between Arab conquest and present-day autocratic governance remains underdeveloped. Although a causal linkage between conquest institutions and authoritarianism certainly seems plausible, Chaney does not convincingly reject the most probable alternative explanations, including that based on diffusion of early Islamic values or culture from the "heartland" outward to the Muslim periphery.

A second important empirical contribution of the paper relates to Chaney's examination of the relationships among Islam's expansion, desert geography, and authoritarian persistence. Chaney finds no robust statistical relationship between rainfall and democracy outside of the countries conquered by Arab armies. This finding suggests that geography matters for authoritarian persistence, but not in the way previously theorized.

THE EMPIRICAL RELATIONSHIP BETWEEN ARAB CONQUEST AND DEMOCRACY What do we know about the empirical relationship between having been subject to Arab conquest during the period of Islamic expansion and the degree of democratization by 2010 ? This is a difficult research question to answer, in no small part because, at the country level, the factors that seem most likely to explain Arab autocracy are all highly correlated with 
each other: countries with Muslim-majority populations tend also to suffer from low precipitation and to have high levels of oil production, and, of course, Arab conquest and Arab culture are highly confounded.

Chaney's ability to draw his conclusion about the impact of Arab conquest depends on the outcomes in areas conquered by Arab armies but not currently culturally "Arab," in particular in the 10 countries that were subject to Arab conquest but are not currently members of the Arab League. Using a normalized polity score from the Polity IV Project, Chaney codes 3 of the 10 as relatively democratic in 2010. Freedom House considers 4 of the 10 as partly free or free in 2012. Although the number of countries coded as more autocratic exceeds those coded as more democratic in both samples, the difference is relatively small. Further, the number of citizens living in the autocratic countries is about half that in the relatively democratic countries (about 140 million versus 280 million). ${ }^{2}$ Given the fact that national borders are political constructs influenced by innumerable historical processes, one would want to confirm that Chaney's conclusions are robust to the inclusion of population weights. ${ }^{3}$

Rerunning Chaney's analysis with a series of population-weighted regressions (results available from the author on request) suggests, however, a slightly different interpretation of the relationship among Arab culture, Arab conquest, and regime type. The coefficient estimates on Arab conquest decrease and are no longer statistically significant. They do, however, remain consistently of the expected sign. Arab League membership (a proxy for Arab "culture"), on the other hand, emerges as a comparably sized (and often more robust) predictor of contemporary authoritarianism than history of Arab conquest. These empirical regularities are consistent with at least one alternative theoretical explanation for the Arab democracy "deficit," namely, that it relates to the diffusion of Arab or Islamic cultural values.

"VALUE" DIFFUSION, COERCIVE CONVERSION, AND CONQUEST VULNERABILITY Chaney's theoretical argument focuses on the long institutional shadow of

2. For example, the four autocratic Central Asian countries of Azerbaijan, Tajikistan, Turkmenistan, and Uzbekistan have a total population of about 50 million; Turkey, with a population of about 70 million, enjoys relatively democratic political institutions. Had these autocratic Central Asian countries remained part of the Soviet Union rather than split off as independent states, Chaney would have reached a different conclusion about the long-term historical legacy of Arab conquest.

3. This is even more the case when one considers the normative motivation for studying regime types: democracy matters insofar as it influences the lives, opportunities, and wellbeing of individual citizens. 
the Arab conquests on the conquered areas. ${ }^{4} \mathrm{He}$ argues that Arab conquest regions enjoyed unusually autocratic political institutions as a result of their propensity to adopt slave armies, where the emergence of such armies encouraged religious leaders to serve as the primary check on Muslim sovereigns (Chaney 2011, 2012). Blaydes and Chaney (2011) describe the theoretical and empirical implications of slave armies for the development of constraints on executive power and of the rule of law, both of which are underpinnings of democratic governance. Although the narrative Chaney describes is plausible, critical pieces of evidence are missing, particularly information suggesting that Arab-conquered areas were more likely to use slave armies than nonconquered Muslim areas. And if areas that maintain Arab "culture" (as indicated by Arab League membership) are even more likely to be autocratic than their non-Arabic-speaking, conquered neighbors as suggested above, could this be because slave armies were yet more pervasive in the Arab "heartland?"

This discussion points to a set of alternative causal mechanisms linking both Arab culture and Arab conquest to authoritarianism through a diffusion of culture, values, or institutions. For example, if the citizens of Arab conquest countries tend to be more devout Muslims, an Islam "effect" may still be relevant. To deal with this issue, Chaney proposes a variety of control variables. To measure women's position in society, for example, he includes a variable for the percentage of parliamentary seats held by women in 2010. However, this measure as an indicator of women's status is problematic for a variety of reasons, the most important of which is that the countries that tend to be most retrograde regarding the treatment of women have been the first to create quotas for female representation in parliament (Bush 2011). Countries like Afghanistan (28 percent female representation in parliament), Iraq (25 percent), Pakistan (22 percent), and Sudan (26 percent) all have more women in parliament than France (19 percent), the United Kingdom (22 percent), or the United States (17 percent). Unless one controls for the existence of these quotas, this variable fails as a measure of women's status in society, particularly for the most gender-regressive societies.

4. On a conceptual level, what is meant by Arab "conquest"? Chaney defines his Arab conquest variable as the proportion of a country's landmass that was ruled by Muslim dynasties in $1100 \mathrm{CE}$ interacted with a dummy equal to 1 if the country's landmass was still controlled by Muslim dynasties in both 1500 and 1900 CE. Spain and other areas conquered but not held by Muslim rulers are thus not coded as conquest areas. This conceptual disconnect has implications for identifying the relevant causal mechanism linking Arab conquest to regime type. 
As a way of measuring the underlying level of religious adherence within a country, Chaney includes a variable measuring alcohol consumption per capita in some of his empirical specifications and finds that it does not diminish the size or the statistical significance of the coefficient on Arab conquest. Yet this variable is potentially subject to a host of measurement problems, not the least of which is the unreliability of self-reported consumption in Muslim societies. Other research suggests that support for Islamic fundamentalism tends to be higher, on average, in Arab cultural and conquest areas than in other parts of the Islamic world (Blaydes and Linzer 2008). The share of votes cast for Islamist political parties also appears to be higher in Arab conquest areas. For example, Islamist candidates recently won about 70 percent and 40 percent of parliamentary seats in Egypt and Tunisia, respectively. Islamist party support in nonconquest Muslim-majority areas, such as Southeast Asia and Muslim sub-Saharan Africa, is much lower.

The evidence Chaney provides does not convincingly rule out the straightforward possibility that a diffusion of Arab or Islamic culture, values, or institutions from the "heartland" to the rest of the Islamic world explains the lack of democracy in the latter. Indeed, the way that Islam expanded beyond the first stages of Arab conquest may also matter for the type of governance that followed. During the period of Arab conquest, invading Muslim tribesmen were seen as a new military elite. Although Islam was not forced on the conquered peoples, the decision whether to convert took place in the shadow of military strength. Islam's spread beyond its $1100 \mathrm{CE}$ borders to places like South and Southeast Asia as well as sub-Saharan Africa has been credited to traders and travelers who facilitated both commercial and intellectual contact between Muslims and non-Muslims. If the manner in which conversion to Islam took place affected the development of other societal norms and institutions, perhaps this might explain the observed differential patterns of political development.

One final confounding factor is worth considering. If the same areas that were susceptible to Muslim conquest were also vulnerable to other types of conquerors, it may be that autocracy in 2010 is the result of either a history of foreign rule or frequent ruler turnover. The region's geographic location (the "Middle" East) has made it for millennia a locus for imperial conflict as well as a destination for nomadic invaders coming off the Asian steppe. The political geography of this region surely has implications for regime type and represents an important area of scholarly investigation. 
ISLAM, GEOGRAPHY, AND POLITICAL INSTITUTIONS An important contribution of Chaney's paper is its exploration of the empirical relationships among Islam, physical geography, and the emergence of political institutions. Stelios Michalopoulos, Alireza Naghavi, and Giovanni Prarolo (2010) show that Islam spread to places with desert geography in part because the religion's redistributive aims appealed to populations in areas with the stark income disparities characteristic of desert environments. An existing literature describes the link between geography and regime type. ${ }^{5}$ Stephen Haber and Victor Menaldo (2010) provide empirical evidence that settled agriculture, which requires at least moderate precipitation, undergirds democracy. Chaney's paper puts these two works in conversation with each other while offering a new empirical contribution.

Chaney finds that climate and geography do matter for regime type, but perhaps not in the way previously theorized. Chaney concurs with Haber and Menaldo (2010) that there is a strong correlation between rainfall and democratic outcomes in 2010. His analysis suggests, however, that this result is driven entirely by countries subject to Arab conquest. Once these countries are excluded, the strong correlation between rainfall and democracy is no longer observed. This finding suggests that Arab conquest, Islam, and physical geography have interacted historically in ways that promote authoritarianism, but that these historical processes remain undertheorized.

\section{REFERENCES FOR THE BLAYDES COMMENT}

Bellin, Eva. 2004. "The Robustness of Authoritarianism in the Middle East: Exceptionalism in Comparative Perspective." Comparative Politics 36, no. 2: 139-57.

Blaydes, Lisa, and Eric Chaney. 2011. "The Feudal Revolution and Europe's Rise: Political Divergence of the Christian and Muslim Worlds before 1500 CE." Stanford University and Harvard University.

Blaydes, Lisa, and Drew A. Linzer. 2008. “The Political Economy of Women's Support for Fundamentalist Islam.” World Politics 60, no. 4: 576-609.

Bush, Sarah. 2011. "International Politics and the Spread of Quotas for Women in Legislatures." International Organization 65, no. 1: 103-37.

Chaney, Eric. 2011. "Revolt on the Nile: Economic Shocks, Religion and Political Power." Harvard University.

5. Arguments relating geography, the nature of agriculture, and regime type have a long intellectual legacy. Wittfogel (1956), for example, considered river valleys as being inclined to authoritarianism, since the organizational structures associated with taming rivers and irrigating crops favored autocracy. 
2012. "Separation of Powers and the Medieval Roots of Institutional Divergence between Europe and the Islamic Middle East." Harvard University. Diamond, Larry. 2010. "Why Are There No Arab Democracies?" Journal of Democracy 21, no. 1: 93-104.

Donno, Daniela, and Bruce Russett. 2004. "Islam, Authoritarianism, and Female Empowerment: What Are the Linkages?” World Politics 56, no. 4: 582-607.

Fish, M. Steven. 2002. "Islam and Authoritarianism." World Politics 55, no. 1: 4-37.

Haber, Stephen, and Victor Menaldo. 2010. "Rainfall and Democracy." Paper presented at the Stanford Workshop in Comparative Politics, October 25.

Kedourie, Elie. 1992. Democracy and Arab Political Culture. Washington: Washington Institute for Near East Policy.

Kramer, Martin. 1993. "Islam vs. Democracy.” Commentary (January): 35-42.

Lewis, Bernard. 1993. "Islam and Liberal Democracy." Atlantic Monthly 271, no. 2: 89-98.

Michalopoulos, Stelios, Alireza Naghavi, and Giovanni Prarolo. 2010. "Trade and Geography in the Economic Origins of Islam: Theory and Evidence.” Nota di Lavoro no. 75.2010. Milan: Fondazione Eni Enrico Mattei.

Ross, Michael. 2001. "Does Oil Hinder Democracy?” World Politics 53, no. 3: 325-61.

- 2012. The Oil Curse: How Petroleum Wealth Shapes the Development of Nations. Princeton University Press.

Stepan, Alfred, and Graeme Robertson. 2003. “An 'Arab’ More Than 'Muslim' Electoral Gap.” Journal of Democracy 14, no. 3: 30-44.

Wittfogel, Karl. 1956. The Hydraulic Civilizations. University of Chicago Press.

GENERAL DISCUSSION Bradford DeLong, channeling the medieval Arab historian Ibn Khaldun, returned to a point that Lisa Blaydes had touched on, that the feebleness of democracy in the Arab world might have more to do with desert ecology than with the influence of 8th-century Islamic institutions. With the notable exception of what is now Iran, the Mohammedan conquests of the 7 th century were conquests mostly of desert lands and peoples. In preindustrial times it was hard, as Khaldun had observed, for the rulers of such peoples to draw much revenue from them-and harder still if the peoples in question were nomadic-because they generate little agricultural surplus to tax. Instead, the governing elites of those empires tended to tax long-distance commerce, with the result that they had only weak economic connections with the people they ruled, and hence little interest in their economic or political development-a relationship reinforced in the present day by the oil economy. 
Distinguishing between the two hypotheses-Arab conquest versus desert ecology - to explain the failure of democracy to gain traction in the Arab world is rendered difficult, DeLong suggested, by the fact that an important contrary data point, namely, Turkey, is consistent with both. The Arab slave armies were checked where the desert meets the Anatolian plateau. Hence one cannot easily say whether Turkey today is overwhelmingly Islamic yet solidly democratic because of its nondesert geography or because of the historical accident that the Byzantine Empire held the line at the threshold of Asia Minor. In striking contrast, the Sassanid Empire to Arabia's northeast was overwhelmed by the invaders and collapsed, notwithstanding that the Iranian plateau does not share the desert ecology of Arabia and North Africa. On that basis, DeLong argued, Chaney's hypothesis will gain or lose support depending on whether today's Iran makes or does not make a successful transition to democracy in the coming decades.

Christopher Carroll agreed that Chaney's data set had too few observations to allow a clear resolution between the competing hypotheses. $\mathrm{He}$ suggested that an important alternative explanatory variable that might perform as well as the Arab conquest variable was a history of separation between church (or mosque) and state. He noted that democracy has tended to be weaker not only in the Muslim than in the Christian world, but also, within Christendom, in those countries where Orthodox rather than Roman Christianity has been dominant, and the eastern church has tended to have a closer relationship with political institutions than has its western counterpart. Separation of church and state might also help explain why India today is democratic whereas Pakistan is not: whatever role religion might have played in subcontinental politics before the British arrived, religious and political institutions were kept separate under British rule. Upon independence, separation of church and state was enshrined in the Indian, but not in the Pakistani, constitution, and this difference seems to have contributed to the two countries' different outcomes.

Following on Carroll's point, Donald Kohn pointed out that several Western European countries had long had autocratic regimes closely tied to the Roman church, and that this arrangement had lasted up until the late 18th or early 19th centuries-indeed, in the case of Spain, into the 20th. Eventually, however, despite this close relationship of church and state, most of these countries had experienced democratic revolutions, and he wondered whether that fact provided any insight into what was happening in today's Arab world. He also wondered to what extent the Internet and other information technologies were empowering people in the Arab countries to demand democracy. 
Ricardo Reis suggested that one could introduce some additional variation into the data set by exploiting the fact that the countries conquered by the Arabs remained under their domination for varying lengths of time. Spain and Portugal, for example, fell under Arab rule along with northern Africa in the 8th century, but unlike northern Africa managed to throw out the invaders only a few centuries later. Might success at establishing democracy, then, be negatively associated with the duration of Arab rule? Further, Reis argued, if one could hypothesize that weakness of democratic institutions was an effect not merely of Arab conquest but of foreign conquest generally-in other words, that it was due to the persistence of hostile alien institutions - that would open the door to a wealth of additional data with which to test the relationship. After all, the history of the world is replete with examples of conquest of one country by another.

Steven Davis proposed another approach to broadening the question posed and expanding the potential data set. He noted that the paper was vague about exactly what institutions or structures of political control imposed by the Arabs had led to the persistence of autocratic regimes in the conquered countries. If one could specify what those institutions or structures are, and identify similar institutions and structures in other places and times, one could then test whether they had similar effects across that larger data set. If they turned out not to have similar effects, that would indicate that there is something else, unique to the Arab conquest region, that explains those countries' lack of democracy. If, on the other hand, the analysis showed that those institutions and structures do predict the persistence of autocracy and resistance to democratization, it would be an important result.

Hélène Rey reminded the Panel that the Arabs also conquered part of France but were stopped at Poitiers in 732. She suggested that another possible impediment to democracy in the Arab world was cultural, namely, the highly patriarchal character of Arab families, which arguably was reflected in the autocratic nature of their social governance. As Olivier Roy, a scholar at the European University Institute in Florence, has argued, this patriarchalism is today being undermined by demographic change, in the form of a fall in fertility rates. Tunisia, for example, now has a fertility rate roughly equal to France's.

David Romer, following up on Rey's comment, observed that the paper reported having tested a number of micro variables and, with one exception related to self-reported happiness, having found they did not predict which countries would experience uprisings during the Arab Spring. He thought this negative result was intriguing and wondered whether demo- 
graphic variables like the one that Rey had mentioned were among those that had been found uninformative. Olivier Blanchard added that unemployment seemed to be an important factor: his understanding was that the Arab Spring had occurred in countries where the youth unemployment rate was above 50 percent, and where, moreover, the unemployment rate was increasing in the skill level, so that there was mass unemployment even among the well educated.

Robert Hall pointed out that classical Rome had established a greater presence in some countries later conquered by the Arabs than in others. This fact suggested yet another possible determinant of Arab democratic success. Was it a coincidence, he wondered, that two of the countries in the Middle East where democracy today seems most hopeful, Tunisia and Turkey, were also among those where Roman influence-as proxied, for example, by the survival of ruins-was greatest? It seemed plausible that Roman institutions could have left a favorable residual 2,000 years later. Hall cited some more recent cases where conquest had had important, even transformative, social impacts, including the British conquests of North America and India, and the U.S. conquests of Japan and Germany (but not, apparently, of Cuba); he also reminded the Panel of research by Daron Acemoglu and James Robinson that focuses on the difference in impacts between British conquest for purposes of settlement, as in North America, and British conquest for purposes of extraction, as in India. All this suggested to Hall that Chaney's basic premise, that conquest can have important and durable effects, was well founded and merited further study.

On the other hand, Hall cautioned against placing too great an emphasis on democratization as the sole measure of success, as if it were the defining character of an advanced society and the indispensable element in economic progress. In fact, in a cross section of countries, democracy correlates negatively with standards of living, not only because of the many small, poor African countries that are at least nominally democratic, but also because one major contemporary economic success story, China, is not a democracy. Singapore, too, made great economic strides under autocracy and only later converted, painlessly, to democracy.

Bradford DeLong questioned Hall's suggestion about the imperial Roman residual, noting that Rome had been interested in Tunisia and Turkey (and Egypt) precisely because they had productive agricultural regions. Thus, the desert ecology effect seemed to prevail, at least in terms of ultimate cause.

Responding to the discussion, Eric Chaney acknowledged that if one is interested in the economic growth of the region, it was unclear why democracy should be the dependent variable. The first-order concern in 
these countries, however, as reflected in interest over the Arab Spring, was whether democracy would in fact emerge. He added that it might be interesting to test an instrumental variable for institutions and examine whether they had an effect on economic development in the long term. Essentially the paper was performing the following thought experiment: if Syria, say, had never been conquered by the Arab armies, what would it look like today? Chaney's hypothesis was that it would look a lot like Greece. Regarding Hall's Roman residual, Chaney thought there were enough countries that had been part of the Roman Empire, yet unlike Turkey were not democratic, and unlike Egypt had not participated in the Arab Spring, to cast doubt on that hypothesis.

On the question of what contemporary variables, such as the unemployment rate or self-reported happiness, might have catalyzed the recent uprisings, Chaney confirmed that he had tested a number of such variables and found almost all to be insignificant. He noted that many of the same catalysts had been present in the past and had not led to popular revolts, or at least not to revolts that ended in democracy being established. The question that interested him was why these catalysts had not led to democracy in the past and what, if anything, was different today.

Responding to DeLong, Chaney conceded that there were no countries in the sample that shared the extreme desert ecology of, for example, Saudi Arabia and Yemen that had not also been conquered by the Arab armies. On the other hand, the sample included several semiarid countries, such as Botswana, Namibia, and Mongolia, that were not conquered and that are democracies today. That, in his view, cast doubt on the desert ecology hypothesis.

Responding to Carroll, Chaney believed that the separation of church and state in Western Europe was endogenous to that region's political development. He agreed that there were some similarities between the Arab conquest countries and the countries where Orthodox Christianity was dominant, but when the comparison is between those two groups, the latter are clearly more democratic. Finally, responding to Kohn, Chaney pointed out that although it took until the 19th century for several Western European countries to establish parliaments, the first parliament was held in Spain in the 12th century, and in fact parliaments have a long history in the region, but little or none in the Islamic world. He saw this as evidence that democratic institutions tend to take a very long time to mature. 